\title{
3 The Transmission of Magentenos' Commentary on Anal. Pr. II
}

\subsection{Manuscripts}

Leon Magentenos' commentary on Anal. Pr. is extant in thirty-two manuscripts. ${ }^{1}$

- In the margins of two of these manuscripts, a small number of individual scholia

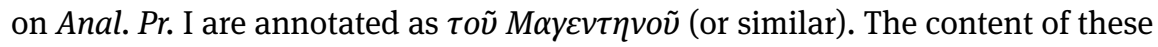
scholia differs from the rest of the tradition, as well as from each another (there is one exception). ${ }^{2}$

- One codex contains a redaction with interpolated extracts that derive from an earlier version of the commentary. ${ }^{3}$

- Ten manuscripts transmit the commentary in its entirety or with minor omissions. ${ }^{4}$

- A further eight codices contain the comments on or large sections of book.$^{5}$

- One codex includes a few sections of the commentary on book II. ${ }^{6}$

- In nine cases excerpts were copied as parts of scholia collections or as part of other commentaries. $^{7}$

- Finally, there exists a manuscript dated to the late fifteenth century that contains an anonymous Latin translation of Magentenos' comments on Anal. Pr. I. ${ }^{8}$

In the following alphabetical classification we list twenty one codices that transmit either the entirety, or parts, or individual scholia of Magentenos' comments on Anal. Pr. II. All entries inlcude a brief description detailing date, physical description, contents and secondary literature. Manuscripts examined in loco are denoted by means of an

1 To these we should add Magentenos' comments in the Basel edition of the Aristotelian corpus of the Iviron monastery on Athos. The excerpts are not considered here; see p. XXIX.

2 Princeton MS 173, ff. 15v, 16r; Vat. Barb. gr. 164, ff. 39r, 65r, 66r, 67rv. A marginal scholion toṽ Mayevtๆuoṽ on Anal. Pr. I 1, $24 a 25$ is to be found in both Princeton MS 173, f. 16r and Vat. Barb. gr. 164, f. 39r.

3 Vat. Urb. gr. 35.

4 Ambr. D 54 sup., Mut. 205, Par. Coisl. 157, 167, Par. gr. 1846, 1972, Vat. gr. 209, 244, 1018, Vat. Reg. gr. 107.

5 Ambr. D 43 sup., Ang. 30, Laur. 71.10, 85.1, Leuven MS FDWM 1, Par. Coisl. 170, Par. gr. 1917, Vat. gr. 317.

6 Vat. gr. 1693.

7 Ambr. Q 87 sup., Esc. Ф.I.14, Lips. Rep. I 68a, Mon. gr. 29, 75, Par. gr. 1974, Vat. gr. 245 (scholia on Anal. Pr. I), Vat. Reg. gr. 116 and Vind. phil. gr. 208.

8 Vat. lat. 4560; see Ebbesen - Pinborg 1981-82, 314-315. 
asterisk $\left(^{\star}\right)$ on the right side of the pertinent shelf mark. Codices, for which I consulted Professor Diether Reinsch's unpublished descriptions are marked with the letter ' $R$ '. ${ }^{9}$

\section{Ambr. D 54 sup. [olim N 46] (= D)}

1272 (ff. 37r-203r, 204rv); 13th c., end (ff. 9r-36v, 203v, 205r-268v); second half of 14th c. (ff. 1rv, 3r-8v); 15th c. (f. 2rv) bombycine (paper: ff. I-III, 1-8, 216, 223-242, 245257, 260, 263-264, 266-267, I'-III') mm 258x130 (ff. 2, 116, 118, 120, 122, 126, 130, 133 , 140, 150, 216-268: fluctuating size between mm 85x130 and mm 258x175) ff. III, 268, III'

Contents: (f. IIr) Table of contents. (f. 1r) Note ducat. decem and the older signature mark of the codex N.46. (f. 1v) Letters. (ff. 2rv) anonymous introduction to the Organon. (ff. 3rv) Astronomical diagrams. (ff. 9r-36v) Cleomedes, De motu circulari corporum caelestium with scholia. (f. 36v) Verses of 〈Ioannes〉 Tzetzes probably deriving from his verse commentary on Porphyrios' Isagoge. (ff. 37r-63v) Ammonios, In Porph. Isag. ～(ff. 42r-64r, 216rv) Porphyrios' Isagoge alternating with Ammonios' commentary. （ff. 64v-113v) 〈Ioannes Philoponos〉, In Cat. （ff. 114r-129r) Commentaries by 〈Ps.-Magentenos (?)〉 and (Leon Magentenos〉 (ff. 129r-148r) on Int. (ff. $118 \mathrm{r}-140 \mathrm{v}$ ) Int. (occasionally in the margins of the commentaries by (Ps.-Magentenos (?)) and (Leon Magentenos)). (ff. 148v-197v, 204rv, 198r-203r) 〈Leon Magentenos〉, In Anal. Pr. copied by Alexios Solymas (the comments on book II begin on f. 191r). (ff. 206r-215v) Anal. Post. （ff. 217r-229v, 251r-253v) Cat. （ff. 230r-250v, 254r-268v, 203v, 205r-206r) Anal. Pr.

Blank folia: Irv, IIv-IIIv, 4r-8v, I'-III'.

Secondary Literature: Martini - Bassi 1906, 266-268; Turyn 1972, 22-23; Pasini 2007, 229; Agiotis 2013, 5 (28); Beta 2014, 37 (2); CAGB Database (link on p. XXIII).

\section{Ambr. Q 87 sup. (= Q)}

Middle to third quarter of 14th c. paper (bombycine: ff. 1-2) mm 290x220 (ff. 192199: mm 290x220) ff. III, 278, I'

Contents: (ff. 1r-2v) Nikephoros Gregoras, De constructione astrolabii. （ff. 3r7v) Matthaios Vlastares, Syntagma canonum. (f. 8rv) A list of metropoleis and archbishoprics. (f. 8v) Explanations of Greek terms originating from Latin. (ff. 9r-10r) A riddle by 〈Vasileios Megalomytes〉; a myth by Aisopos; an epigram by Isaac Argyros dedicated to Ioannes Chrysostomos; epigrams (one of them, on f. 10r, on the Organon); a diagram on the division of philosophy; indices concerning Porphyrios, Isagoge and Cat. (ff. 10r-21r) Porphyrios, Isagoge with the commentary of 〈Ammonios〉 (excerpt).

9 These documents are kept in the Aristoteles-Archiv (Freie Universität Berlin). 
(ff. 21v-23v) Individual anonymous scholia on Porphyrios, Isagoge and Cat. （ff. 24r49r) Cat. with scholia. (ff. 53r-76r) Int. with the commentary by Ammonios (from $\mathrm{f}$. 49r). (ff. 79v-191v) Anal. Pr. and a commentary attributed to Philoponos (from f. $76 \mathrm{v}$ ). This work (henceforth referred to as Philoponos 2) consists of an abridged version of Ioannes Philoponos' comments, excerpts from Alexander of Aphrodisias' commentary and Leon Magentenos' prooimion of his commentary on Anal. Pr. II (the latter text may be found on f. 149v). ${ }^{10} \quad$ (ff. 192r-199v) Euclides, Elementa with scholia. (ff. 200r-202v) 〈Maximos Planoudes〉, Prolegomena in rhetoricam. (ff. 204r-217v) Aphthonios, Progymnasmata with scholia (from f. 202v). (ff. 220v-221v) Hermogenes, De statibus with 〈Maximos Planoudes〉, Prolegomena (ff. 218r-219v) and an index (f. 220). (ff. 222r-223v, 227r-229v) Galen, De ossibus ad tirones. (ff. 224r-226v, 230r-240v) Galen, De musculorum dissectione ad tirones with anonymous texts which are medical in nature (f. 241r). (ff. 241v-270v) Text on medicinal plants. (ff. 271r-278v) Paulos Aiginetes, Epitome medica (excerpts).

Blank folia: 23r.

Secondary Literature: Martini - Bassi 1906, 791-794; Touwaide 1992, 291 (3); Debru - Garofalo 2005, 17; Pasini 2007, 307-308; CAGB Database (link on p. XXIII).

\section{Esc. $\Phi .1 .14\left(=E^{\mathrm{m}}\right)$}

Middle of 16th c. paper mm 325x233 ff. I, 273

Contents: (ff. 1r-9v) An anonymous commentary, i.e. an interpolated version of Leon Magentenos, In Anal. Post. (on ff. 5v-6r scholion 157 of Magentenos' commentary on Anal. Pr. II). ${ }^{11} \quad$ (ff. 10r-158r) Eustratios, In Anal. Post. II. （ff. 161r-176v, 177v-243r) Scholia on the Phys. and an anonymous commentary on the latter work (from f. 166v). (ff. 246r-268v) 〈Olympiodoros〉, In Mete. (ff. 269r-273r) Anonymous scholia on Part. An. I. and on Plant. II.

Blank folia: 158v-160v, 177r, 243v-245v, 248v, 255r.

Secondary Literature: De Andrés 1965, 21-22; Agiotis 2015, 5, 83-98; Pinakes (link on p. XXIII).

\section{Lips. Rep. I 68a (= I)}

after 1442 (ff. 1r-30v); 15th/16th c. (ff. 31r-54v) paper mm 280x210 ff. I, 54, II'

Contents: (ff. 1r-30v) Passages from Anal. Pr. I with 〈Philoponos 2$\rangle$ in the margins (excerpts). The prooimion by 〈Leon Magentenos〉 on book II can be found in the lower

10 See also the entries on codices Lips. Rep. I 68a, Par. gr. 1974, Vat. Reg. gr. 116 and Vind. Phil. gr. 208.

11 See also the entries on codices Mon. gr. 29, 75 and Utin. gr. 256. 
margin of f. 15r. (ff. 31r-54v) 〈Ioannes Philoponos〉, In Anal. Pr. I (excerpt). Blank folia: Irv, II'rv.

Secondary Literature: Moraux 1973, 412-413; CAGB Database (link on p. XXIII); Manuscripta Mediaevalia (link on p. XXIII).

\section{Mon. gr. $29\left(=M^{k}\right)$}

ca. 1550 paper mm 350x244 ff. I, 420, I'

Contents: (f. Irv) folio bearing adhesively affixed leaves with the description of the codex in Hardt 1806, 162-170. (ff. 1r-54v) Proklos, In Platonis Cratylum commentaria. (ff. 55r-91v) Theon of Smyrna, Expositio rerum mathematicarum. (ff. 92r-101r) Excerpts from the work of Atticus. (ff. 101r-104r) Georgios Gemistos Plethon, Oratio funebris in Helenam Palaeologinam. (ff. 104r-105v) Anonymous astronomical texts. (ff. 105v-106r) Epitheta deorum. (ff. 106r-107r) Excerpts from the work of Hero of Alexandria. (ff. 108r-159r, 170v-175v) Nemesios, De natura hominis. (ff. 160r-165r) Markos Eugenikos, Oratio de vitae termino. (ff. 165r-170v) 〈Markos Eugenikos〉, Tractatus de resurrectione. (ff. 176r-182v) An anonymous commentary, i.e. an interpolated version of Leon Magentenos, In Anal. Post. (on ff. 179v-180r scholion 157 of Magentenos' commentary on Anal. Pr. II). ${ }^{12}$ (ff. 183v-315r) (Eustratios〉, In Anal. Post. II. (ff. 316r-396v) Works by Synesios of Kyrene. (ff. 397r-413r) Nikephoros Gregoras, Explicatio in Synesii De insomniis (excerpts).

Blank folia: 91Arv, 107v, 159v, 159Ar-159Dv, 183r, 315v, 384v, 396Ar-396Bv, 413v, I'rv.

Secondary Literature: Tiftixoglou 2004, 179-186; Valente 2021c; MDZ (link on p. XXII); Pinakes (link on p. XXIII).

\section{Mon. gr. $75\left(=\mathbf{N}^{\mathrm{k}}\right)$}

ca. 1550 paper mm 347x240 ff. I, 407, I'

Contents: (f. IIv) folio bearing adhesively affixed leaves with the description of the codex in Hardt 1806, 451-453. (ff. 1r-112v) Maximos of Tyre, Orationes. （ff. 113r123r) An anonymous commentary, i.e. an interpolated version of Leon Magentenos, In Anal. Post. (on ff. 118r-119v scholion 157 of Magentenos' commentary on Anal. Pr. II). ${ }^{13}$ (ff. 124r-295v) (Eustratios), In Anal. Post. II. （ff. 297r-332v) Rhet. Al. (ff. 333r-399v) Scholia on Aischylos' works.

Blank folia: Ir-IIr, 112Ar-112Bv, 123v, 296rv, 332Ar-332Cv, 339Ar-399Bv.

Secondary Literature: Molin Pradel 2013, 152-156; Valente 2021c; MDZ (link on p. XXII); Pinakes (link on p. XXIII).

12 See also the entries on codices Esc. Ф.I.14, Mon. gr. 75 and Utin. gr. 256. 13 See also the entries on codices Esc. Ф.I.14, Mon. gr. 29 and Utin. gr. 256. 


\section{Mut. 205 [olim $\alpha . W .3 .18]$ (= M)}

First half of the 16th c. paper mm 334x234 ff. I, 300, I'

Contents: (f. 1r) Note 352. (f. 1v) Note on the Aristotelian commentaries in the codex. (ff. 2r-7r, 11r-247r) Anal. Pr. I with the commentaries by Alexander of Aphrodisias (excerpts on ff. 178r-182v) and Ioannes Philoponos, a text on hypothetical syllogisms attributed to Psellos and then the commentary by Leon Magentenos (from f. 109r). (ff. 7v-10r) Excerpts from Euclides, Elementa with scholia ascribed to

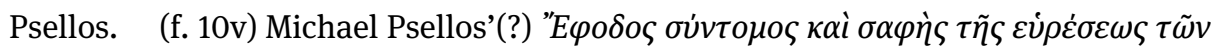
$\sigma v \lambda \lambda о \gamma \iota \sigma \mu \tilde{\omega} v \tau \tilde{\omega} \nu \tau \rho \iota \tilde{\omega} v \sigma \chi \eta \mu \alpha \dot{\alpha} \omega \nu$. (ff. 247v-298v) Leon Magentenos, In Anal. Pr.

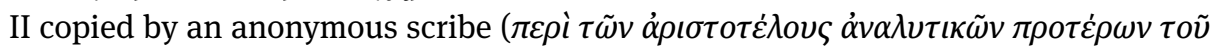

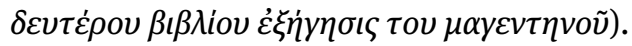

Blank folia: $299 \mathrm{r}-300 \mathrm{v}$.

Secondary Literature: Puntoni 1896, 506-507; De Gregorio - Eleuteri 1993, 158159; Moore 2005, 247-248, 566; CAGB Database (link on p. XXIII).

\section{Par. Coisl. 157 (= E)}

after 1330 parchment mm 370x268 ff. $614(+118 \mathrm{a}, 171 \mathrm{a})$

Contents: (ff. 1r-27r) Porphyrios, Isagoge with the commentaries by 〈Ammonios〉 and (Leon Magentenos). (ff. 29v-100v) Cat. with the commentaries by Simplikios (excerpts from f. 27r) and Leon Magentenos (ff. 29r-101r). (ff. 104v-174r) Int. with the commentaries by 〈Ammonios〉 (ff. 101r-174v and ff. 202v-204r) and (Leon Magentenos〉 (ff. 102r-174v). (f. 175r) Diagram. (ff. 175v-179v) 〈Michael Psellos (?),

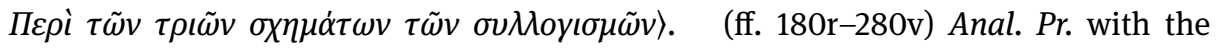
commentaries by 〈Leon Magentenos〉 (from f. 179r; on ff. 254v-280v the 'Metochitesschreiber' (Michael Klostomalles?) copied the commentary on the book II alternating it with the Aristotelian text), 〈Ioannes Philoponos〉 (excerpts) and Alexander of Aphrodisias. (ff. 281v-361v) Anal. Post. with the commentaries by Leon Magentenos (ff. 281r-331r) and (Ps.-Philoponos〉 (ff. 331v-362r) on books I and II respectively. (ff. 363v-524v) Top. with the commentaries by (Leon Magentenos) (excerpts; ff. 362r524v) and Alexander of Aphrodisias. (ff. 526v-614r) Soph. El. with the commentaries by 〈Michael of Ephesos〉 (excerpts from f. 525r) and 〈Leon Magentenos〉 (ff. 526r-614v).

Secondary Literature: Devreese 1945, 140-142; Ebbesen 1981b, III, 70-71, 288; Prato 1991, 146-147; Kotzabassi 1999, 22-23 (75), 49, 53-56; Moore 2005, 249, 559560; Lamberz 2006, 44-45; Brockmann 2019, 222-223; Valente 2021a; Pinakes (link on p. XXIII). 


\section{Par. Coisl. 167 (= S)}

First half of $14 \mathrm{c}$. parchment mm 305x222 ff. I, 317

Contents:(f. Irv) Subscriptions and notes. (ff. 1r-112v) Leon Magentenos, In Soph. El. (ff. 113r-178r) Leon Magentenos, In Anal. Pr. (on f. 145v begin the comments on book II). (178v-317r) (Leon Magentenos〉, In Anal. Post. I (until f. 256v) and 〈Ps.-Philoponos〉, In Anal Post. II.

Blank folia: $317 \mathrm{v}$.

Secondary Literature: Devreese 1945, 149-150; Ebbesen 1981b, III, 70-71, 288; Brockmann 2019, 222-223, 224 (50); Valente 2021a; Pinakes (see p. XXIII).

\section{Par. gr. 1846 (= P)}

Second half of 14 th c. paper mm 278x205 V, 185, III $^{\circ}$

Contents: (ff. 1-4r) The prooemion of the commentary by Ioannes Philoponos on Anal. Pr. I. (ff. 4r-6r, 13r-14r) Euclides, Elementa (excerpts) alternating with scholia that are ascribed to Psellos (ff. 4r-6r). (ff. 6v-13r) Nicomachos of Gerasa, Introductio arithmetica with the comments by Ioannes Philoponos. (f. 15r) Michael

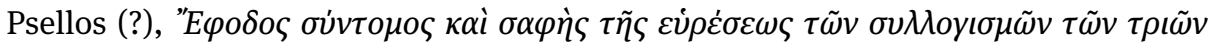
$\sigma \chi \eta \mu \dot{\alpha} \tau \omega \nu$. (ff. 15v-185r) Anal. Pr. with the commentaries by Leon Magentenos (from f. 19v) Ioannes Philoponos (on book I), Ps.-Philoponos (book II), Alexander of Aphrodisias (excerpts), Themistios (excerpts), Ammonios (excerpts), Michael Psellos (excerpts of his Paraphrasis), Neophytos Prodromenos (individual scholia) and Ioannes Chortasmenos (individual scholia). In the margins of ff. 146r-182r 〈Neophytos

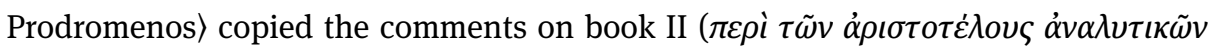

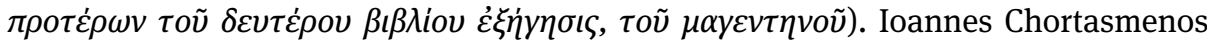
copied an excerpt from an earlier passage in Magentenos' commentary on Anal. Pr.

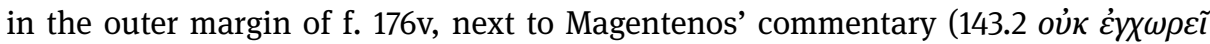

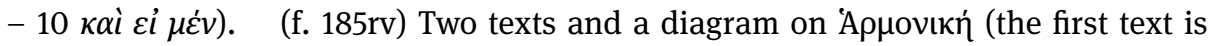
attributed to Ioannes Philoponos, whereas the second one along with the diagram to Nikephoros Gregoras).

Blank folia: 14v.

Secondary Literature: Omont 1888, 152; Cacouros 1998, 188, 191-195; Berger 2005, 141; Bravo - Pérez 2005, 456; Cataldi Palau 2008, 213; Gastgeber 2010, 416; Moore 2005; 247-248; CAGB Database (link on p. XXIII); Gallica (link on p. XXII).

\section{Par. gr. 1972 (= F)}

First half of 14 th c. bombycine mm 342x242 III, 769, III' 
Contents: (ff. $2 \mathrm{v}-5 \mathrm{v}, 8 \mathrm{r}-33 \mathrm{v}$ ) Porphyrios, Isagoge alternating with the commentaries by 〈Ammonios〉 (from f. 1r) and Leon Magentenos (from f. 1v). (ff. 36r-117r) Cat. with the commentaries by Simplikios (excerpts from f. 33v) and Leon Magentenos (ff. 35v-118v). (ff. 121r-202v) Int. with the commentaries by 〈Ammonios〉 (excerpts) and

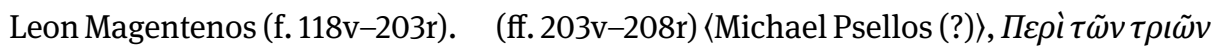

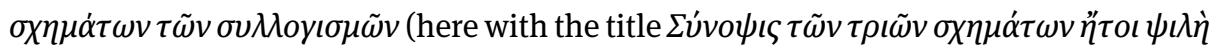

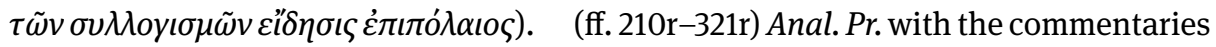
by 〈Ioannes Philoponos〉 (excerpts), Alexander of Aphrodisias and Leon Magentenos (ff. 209r-321r; from f. 290r the comments on book II alternating with the Aristotelian text). (ff. 322r-436r) Anal. Post. alternating with the commentaries by 〈Philoponos〉 and Leon Magentenos (from f. 321v) on book I, as well as with the commentary of 〈Ps.-Philoponos〉 on book II (ff. 391r-437r). (ff. 439v-654r) Top. alternating with the commentaries by 〈Alexander of Aphrodisias〉 (excerpts) and Leon Magentenos (from f. 437v). (ff. 656v-768r, 7rv, 769rv) Soph. El. with the commentaries by (Michael of Ephesos〉 (excerpts from f. 654v) and 〈Leon Magentenos〉 (from f. 656r).

Blank folia: 35r, 208v, 236v.

Secondary Literature: Omont 1888, 22, 48, 53-56; Ebbesen 1981b, III, 287; Kotzabassi 1999, 22, 48, 53-56; Léannec-Bavavéas 1999, 301; Moore 2005, 259-260; Muratore 2009, I, 252-3, 302, 319 (14), 345; II, 57, 405, 448, 503, 532, 575-576, 686, 780; Brockmann 2019, 222-225; Valente 2021a; CAGB Database (link on p. XXIII); Gallica (link on p. XXII).

\section{Par. gr. 1974 (= Z)}

ca. 1451 paper mm 290x198 IV, $330(+330 \mathrm{a}-\mathrm{c})$, III $^{\circ}$

Contents: (ff. 1r-7v, 9r-19r) 〈Ammonios〉, In Porph. Isag. （ff. 7v-8r) Introductory text on logic. (f. 8v) Vita Aristotelis. (f. 19rv) Text on Cat. (ff. 20r-37r) Porphyrios' Isagoge with the commentary by Ammonios (excerpts). (ff. 37r-42v) Ammonios, In Cat. (ff. 44r-87v) Cat. with the commentaries by 〈Ammonios〉 and 〈Philoponos〉 (excerpts). (ff. 88r-92r) 〈Ammonios〉, In Int. (excerpts) (f. 92r) Scholion of a certain Isaak (Argyros?) on the quality and quantity of premises. (ff. 94r-137v) Int. with the commentaries by 〈Ammonios〉 and 〈Leon Magentenos〉. (ff. 144r-292v) Anal. Pr. with the commentary by 〈Philoponos 2〉 on Book I (ff. 138r-142r; see p. XLIX). 〈Ioannes Eugenikos〉 has copied the prooimion of Leon Magentenos' commentary on Anal. Pr. II

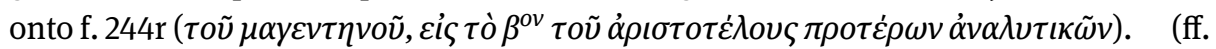
294r-330r) Anal. Post.

Blank folia: 43rv, 92r-93v, 142v-143v, 234v-235r, 293rv, 313v, 330v-330cv.

Secondary Literature: Omont 1888, 173; RGK II, n. 217; Muratore 2009, I, 377 (35); Laffitte 2010 (link to the inventory on p. XV); CAGB Database (link on p. XXIII); Gallica (link on p. XXII). 


\section{Utin. gr. $256\left(=U^{a}\right)$}

1471-1487 (ff. 1r-180r); 1301-1325 (ff. 181r-204r) paper mm 280x200 ff. 204

Contents: (ff. 1r-10r) An anonymous commentary, i.e. an interpolated version of Leon Magentenos, In Anal. Post. (on ff. 5v-6v scholion 157 of Magentenos' commentary on Anal. Pr. II). ${ }^{14} \quad$ (ff. 11r-179r) Eustratios, In Anal. Post. II. $\quad$ (ff. 181r-204r) Rhet. Al. Blank folia: $10 \mathrm{v}, 179 \mathrm{v}-180 \mathrm{v}$.

Secondary Literature: Mioni 1965, 440-441; Formentin 1987, 51-52; Vendruscolo 2006-07, 290, 292-293; Bieker 2015; Valente 2021c; Pinakes (link on p. XXIII).

\section{Vat. gr. $209 * R(=Y)$}

End of 14th c. paper (f. 219: parchment) mm 295x207 ff. II, 219

Contents: (f. Ir) Signature mark. (f. IIr) Table of contents. (f. IIv) A list of the commentators on the Anal. Pr. (ff. 1r-16v) (Georgios Chrysococces, Expositio in Constructionem Persarum). (ff. 17r-32r) Astronomical tables. (f. 36rv) Euclides, Elementa (excerpts) with scholia ascribed to Psellos. (f. 37v) Michael Psellos (?),

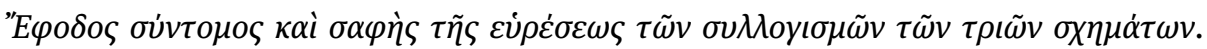
(ff. 38r-181v) Anal. Pr. along with the commentaries by Leon Magentenos (from f. 41v), Ioannes Philoponos (on book I starting from f. 33r), Ps.-Philoponos (on book II), 〈Michael Psellos〉 (excerpts of his Paraphrasis on ff. 107v-108r, 109r-110r, 111v, 113r, 114r, 115r, 118r, 119r, 120v, 122rv, 123v), Ps.-Themistios, Neophytos Prodromenos (individual scholia), Alexander of Aphrodisias (excerpts) and Ammonios (excerpts). In the margins of ff. $144 \mathrm{v}-175 \mathrm{v}$ an anonymous scribe copied the comments of Ma-

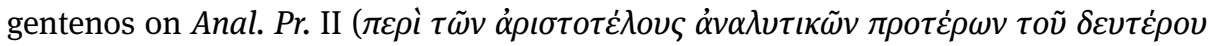

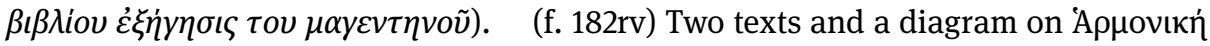
(the first text is attributed to Ioannes Philoponos, whereas the following diagram with the text are ascribed to Nikephoros Gregoras). (ff. 184r-218v) Anal. Post. I with the commentary of Ioannes Philoponos (starting from f. 183r) and scholia ascribed to Themistios, Apollonios, Proklos, Leon Magentenos and Neophytos Prodromenos. (f. 219v) Buying contract in Latin (the second leaf of the bifolio, which contains the last part of the contract, is fixed on the binding of the codex).

Blank folia: I'v, 32v, 219r.

Secondary Literature: Mercati - Franchi de' Cavalieri 1923, 258-261; Tihon 1987, 486; Ierodiakonou 1996, 104; Cacouros 1998, 189; Mondrain 2000, 14; Berger 2005, 141; Moore 2005, 247; Pinakes (link on p. XXIII); DVL (link on p. XXII). 


\section{Vat. gr. $244^{\star R}(=$ V)}

12th/13th c. bombycine fluctuating size between mm 350x258 and mm 355x265 ff. V, 652, II' (+120-129 bis, 157a, 170a)

Contents: (f. Vr) Table of contents. (ff. 1r-2v) Ammonios, In Porph. Isag. (excerpts). (ff. 4v-31v) Porphyrios, Isagoge Leon Magentenos' commentary (ff. 3r-28). The scribe's scholia were adjusted as a second layer of exegetic material in the margins around Magentenos commentary. The anonymous copyist follows this method throughout the codex. (ff. 32v-89r) Cat. with 〈Leon Magentenos'> (ff. 32r-90r) and Simplikios' (excerpts from f. 31v) commentaries. (ff. 93r-132v) Int. with Leon Magentenos' (from f. 91r) and Ammonios' (first excerpt on f. 90v; the last one ends on f.

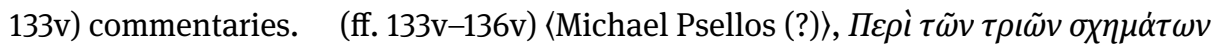

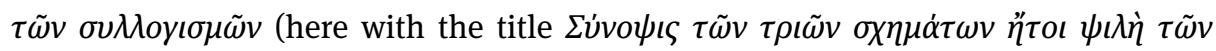

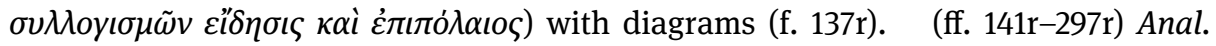
Pr. with Leon Magentenos' (from f. 139r; on ff. 240r-296v the comments on book II), Alexander of Aphrodisias' (excerpts), 〈Ammonios'〉 and 〈Ioannes Philoponos'〉 (book I) commentaries. On ff. 166v-168r Ammonios, In Int. (excerpt). (ff. 301v-416r) Anal. Post. with 〈Leon Magentenos'〉 (from f. 301r) and 〈Ioannes Philoponos'〉 (from f. 369v) commentaries on book I and II respectively. (ff. 417r-581r) Top. with (Leon Magentenos'〉, 〈Alexander of Aphrodisias'〉 (excerpts; the last one on f. 568v) commentaries. (ff. 583v-652r) Soph. El. with 〈Leon Magentenos'〉 (from f. 583r) and Michael of Ephesos' (from f. 581v; excerpts) commentaries.

Blank folia: Ir-IVv, Vv, 137v-138v, 169rv, 219rv, 239v, 297r-300v, 416v, I’r-II'v.

Secondary Literature: Brandis 1831, 50; Mercati - Franchi de' Cavalieri 1923, 313317; Ebbesen 1981b, I, 302, 314; ibid. III, 289; Hunger 1990-91, 34; Hunger 1991, 74-75; Kotzabassi 1999, 25, 49, 50-51; Cavallo 2000, 232; Moore 2005, 249, 560; Brunschwig 2007, xlviii (82); Agiotis 2015, 4-5; Brockmann 2019, 219-224; Valente 2021a; Pinakes (link on p. XXIII); DVL (link on p. XXII).

\section{Vat. gr. $1018^{\star R}(=R)$}

15th c. paper (ff. I, II, 675: parchment) mm 292x215 (f. 221A: mm 130x100; f. 278A: 207x135) ff. II, 675 (+ 1a, 7a, 101 bis, 154a, 221a, 261a, 278a, 421a, 501a, 601a, 633a, 643a)

Contents: (ff. Ir-IIr) Signature marks of the codex. (f. IIv) Note in Latin in

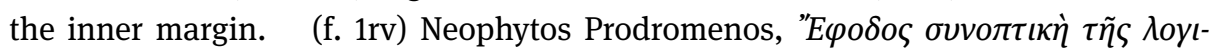

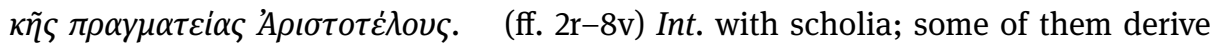
from the relevant commentaries by Leon Magentenos (f. 6v) and Ammonios (from f. 7). (ff. 9r-36r, 69r-70r) David, In Porph. Isag. (ff. 36v-68v) David, In Cat. (ff. 70r-72v) Anonymous text on Int. (ff. 72v-81r) Two anonymous texts on Anal. Pr.:

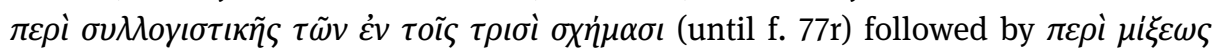




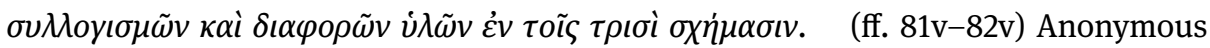
text on Soph. El. (ff. 84r-90v) Ammonios, In Porph. Isag. with diagrams (f. 90v). (ff. 91r-103v) Porphyrios, Isagoge with scholia. (ff. 107r-154Ar) Cat. with the commentaries of 〈Ammonios〉 and 〈Ioannes Philoponos〉 (excerpts until f. 154Ar). (ff. 155r-173r) Int. with marginal scholia. (ff. 174r-175r) Ammonios, In Int. (ff. 175v-

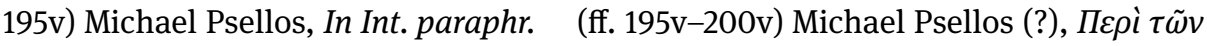
$\tau \rho \iota \tilde{\omega} v \sigma \chi \eta \mu \alpha \dot{\alpha} \omega \nu \tau \tilde{\omega} v \sigma v \lambda \lambda o y \iota \sigma \mu \tilde{\omega} v . \quad$ (ff. 203r-205r) Ioannes Philoponos, In Anal. Pr. I and Ps.-Philoponos, In Anal. Pr. II （ff. 208r-354v) Anal. Pr. with Michael Psellos'(?)

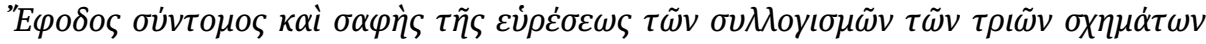
(f. 211), the commentaries by Alexander (from f. 272r) and Leon Magentenos (from f. 291v). Two anonymous scribes undertook the task of copying Magentenos' comments

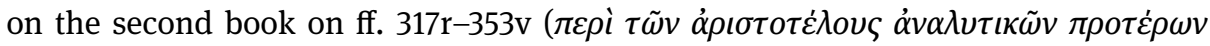

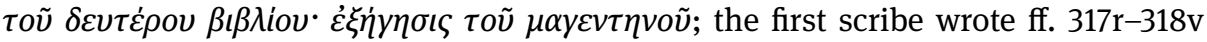
while the second scribe ${ }^{15}$ wrote ff. $319 \mathrm{r}-353 \mathrm{v}$ (from f. 319r onwards the commentary of Magentenos is copied in the margins of the Aristotelian text). Excerpts from the New Testament can to be found on f. 221Arv. (ff. 355r-472v) Anal. Post. with the commentary of Philoponos on book I; the comments of Ps.-Philoponos on book II (ff. 449r-480v) are attributed to Magentenos (see above p. XXVIII). On f. 446r an excerpt from Alexander, In Top.; on ff. 446r-447v two individual scholia on Cat.; on f. 447v excerpt from Ps.-Ammonios, In Anal. Pr. (ff. 482r-599v) Top. with the commentaries by Leon Magentenos (ff. 481r-594v) and Alexander of Aphrodisias (excerpts). (ff. 608r-654v) Soph. El. with the commentary by Michael of Ephesos (ff. 601r-674v); here, the latter work is attributed to Ammonios.

Blank folia: Ir, IIr, 5rv, 7v, 83rv, 90r, 104v-106v, 133v, 154Av, 173v, 201r-202v, 205v207v, 211v, 221r, 238v, 270v, 286r-287v, 342rv, 445v, 501v, 553v, 599v-600v, 634v.

Secondary Literature: Brandis 1831, 52-53; Mercati 1926, 77; Mioni 1976, 311; Ebbesen 1981b, II, xvii, xxxii, xxxvii; III, 290; Cacouros 1998, 188-190, 194; Mondrain 2000, 14; Kotzabassi 2002, 24, 49, 51-53, 56-57; Berger 2005, 141; Bravo - Pérez 2005, 456, 460; Moore 2005, 248, 560; Canart 2008, 52; Cataldi Palau 2008, 203; Muratore 2009, 74 (1); Pinakes (link on p. XXIII); DVL (link on p. XXII)].

\section{Vat. gr. $1693(=\mathrm{X})$}

14th/15th c. paper mm 243x159 ff. VI, 398

Contents: (ff. 1r-19r) 〈Ioannes Damaskenos, Dialectica (excerpts from the recensio fusior). (f. 19v) Single scholion on Soph. El. (ff. 20r-27v) Porphyrios, Isagoge. (ff. 28r-42v) Cat. （f. 42v) Verses attributed to 〈Michael Psellos〉. (ff. 43r-100v) Ammonios, In Porph. Isag. (ff. 101r-159r) Ammonios, In Cat. with the commentary of

15 Cf. Cacouros 1998, 189-190; the author suggests that this scribe should be identified with Georgios Tribizias (1423-1485); on Tribizias see RGK, I, n. 73; Liakou-Kropp 2008. 


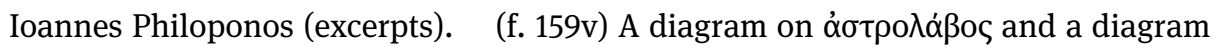
on $\dot{\alpha} \rho \mu$ ovıкń. ～(ff. 160r-204r) Michael Psellos, In Int.paraphr. (ff. 205r-212v) (Leon Magentenos $\rangle$, In Anal. Pr. II (chapters VII-XI copied by an anonymous scribe). (ff. 213r-223r) Int. with scholia (one of them on f. $214 \mathrm{v}$ is attributed to Michael Psellos). (f. 223v) Syllogistical diagrams displaying the fourteen valid moods of the three figures and scholia. (ff. 224r-283r) Anal. Pr. with scholia. （ff. 283r-321r) Anal. Post. (f. 321rv) Ioannes Pediasimos on In Anal. Post. (excerpts). (ff. 322r-379r) Top. (ff. 379v-395v) Soph. El.

Blank folia: 204v, 280v.

Secondary Literature: Gianneli - Canart 1961, 15-18; Kotter 1969, 36; Canart 1979, 55 (239, 241); Moore 2005, 521-22; Pinakes (link on p. XXIII); DVL (link on p. XXII).

\section{Vat. Reg. gr. $107^{*}$ (= K)}

End of 14th c. paper mm 320x260 ff. I, 488, I' (+ 465a)

Contents: (ff. 3r-16r) Porphyrios' Isagoge with anonymous comments starting from f. 1r. (ff. 18v-56v) Cat. with the commentary by 〈Leon Magentenos〉 (from $\mathrm{f}$. 17r). (ff. 58r-92r) Int. with the commentary by 〈Leon Magentenos〉 (from f. 57r). (ff.

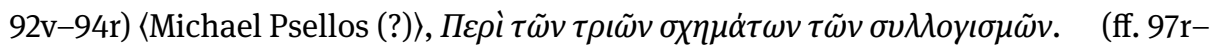
211v) Anal. Pr. with the commentary by 〈Leon Magentenos〉 (from f. 95r). The anonymous copyist filled the margins of ff. 172r-210v with Magentenos' comments on book II (schol. 21-227 with omissions) and inserted excerpted material from 〈Ps.-Philoponos'〉 commentary and from other anonymous sources. (ff. 211v-281r) Anal. Post. with the comments by 〈Leon Magentenos〉 (ff. 211r-255r) and 〈Ps.-Philoponos〉 (from f. 255r) on books I and II respectively. (ff. 281r-439r) Top. with the commentary by (Leon Magentenos $\rangle$ (until f. 438v). (ff. 440r-488v) Soph. El. with the commentary by 〈Michael of Ephesos $\rangle$ (ff. 439r-488r).

Blank folia: Irv, 16v, 41v, 88v, 94v, 95v, 107v, 198v, I'rv.

Secondary Literature: Stevenson 1888, 77; Ebbesen 1981b, III, 289; Kotzabassi 1999, 25, 47 (3); Brockmann 2019, 222-225; Valente 2021a; Pinakes (link on p. XXIII); DVL (link on p. XXII).

Vat. Reg. gr. 116 * (= G)

14th/15th c. paper mm $284 \times 220$ I, 393, I' (+ 60, 62, 63, 74, 125: bis)

Contents: (f. Ir) Note (in Latin) on the Aristotelian content of the manuscript and signature marks. (ff. 1r, 3r-6v) Ammonios, In Porph. Isag. (f. 1v) A diagram on Anal. Pr. I (the so-called pons sinorum; see e.g. Wallies 1905, 274). (ff.

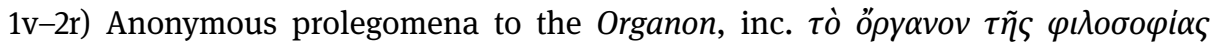

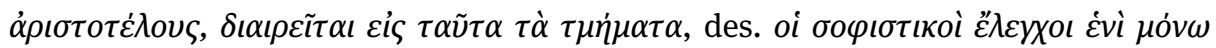




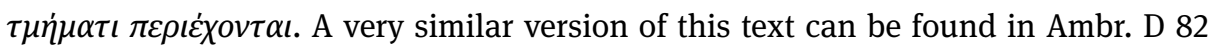
sup., f. 39r (13th c.) and in Par. gr. 2062, f. 133r (14th c.). (f. 2r) Ps.-Alexander's letter

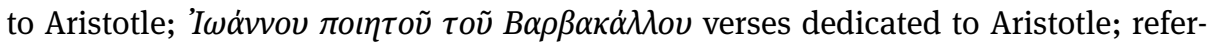
ences to the work titles of the corpus aristotelicum; epigram to the Organon; Isaak Argyros on the Organon. (f. 2v) Note concerning Ammonios' dating. (ff. 7r-24v) Porphyrios, Isagoge with scholia (until f. 24r); one of the scholia is ascribed to the patriarch Photios (f. 13v). (f. 25r) Vita Aristotelis. (f. 25v) Ioannes Philoponos, In Cat. (excerpt). (ff. 26r-27r) Ammonios, In Cat. (excerpts). (ff. 27r-28v) Ammonios, In Int. (excerpts). (f. 28v) Isaac Argyros, In Int. (single scholion). (ff. 29r-58v) Cat. with scholia; one of them is attributed to Photios (f. 42v). (ff. 58v-75v) Int. with

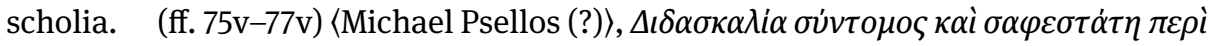

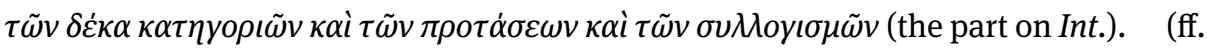
$77 \mathrm{v}-79 \mathrm{v}$ ) Anonymous compendium on assertoric and nonmodal syllogisms (roughly Anal. Pr. I 4-26). (ff. 79v-80r) Anonymous text on the hypothetical syllogisms. (ff. 80v-82r) Anonymous scholia on Cat., Int. and Anal. Pr. (f. 82r) Prolegomena to

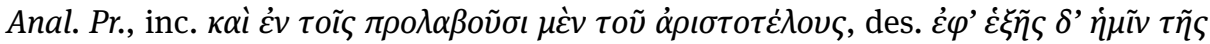

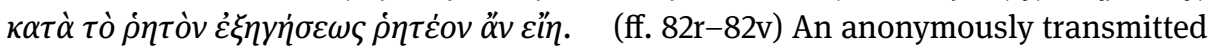

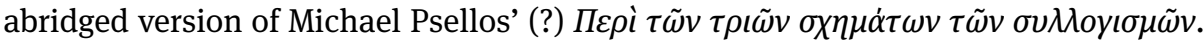

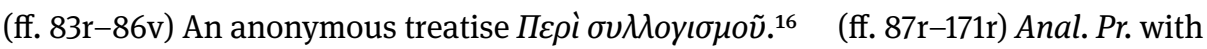
the commentary by Philoponos 2 (see p. XLIX) (on f. 145v the prooimion by 〈Leon Magentenos), In Anal. Pr. II); scholia ascribed to Isaac Argyros (ff. 89v, 162v); an explanation of a diagram on Anal. Pr. which is attributed to a certain Alousianos (f.

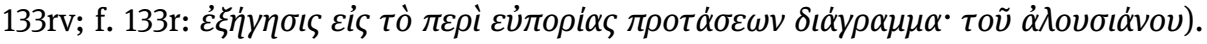
(ff. 174v-227v) Anal. Post. with an anonymous commentary (ff. 172r-173v, 204v-227v). (ff. 233r-342v) Top. with an anonymous commentary (ff. 230v-341v). (ff. 342v-392v) Soph. El. with an anonymous commentary (ff. 343r-387v). (f. 393r) Anal. Pr. with scholia.

Blank folia: Iv, 171v, 228r-230r, 232v, 392v, I'rv.

Secondary Literature: Brandis 1831, 51-52; Stevenson 1888, 81-83; Wallies 1905, xv-xvii; Ebbesen 1981b, I, 291; ibid. III, 289; Kotzabassi 1999, 25, 47 (3); Moore 2005 240, 249; Pinakes (link on p. XXIII); DVL (link on p. XXII).

\section{Vat. Urb. gr. $35^{\mathrm{R}}(=\mathrm{U})$}

Before 902/903 parchment mm 270x215 (ff. 247, 272, 329-332: mm 270 x ca. 120; the outer margins of these folia were cut off) ff. I, 441, I' (+ 380a-f)

16 There are three versions of this text attibuted either to Neilos Kabasilas (ca. 1300 - 1363), or to his nephew, Nikolaos Chamaetos Kabasilas (1319/1323 - after 1391); see Agiotis 2021c. On the Latin translation of the text which is ascribed to Neilos Kabasilas, see p. LXI. 
Contents: (ff. 1r-2v) Division-diagrams related to Porphyrios, Isagoge, a short text on the six definitions of philosophy and a prooemion to the following work. (ff. 3r-20v) Porphyrios, Isagoge with scholia and pertinent diagrams (f. 21r). (ff. 22r$54 \mathrm{v}$ ) Cat. with comments (from 21v). (ff. 54v-74v) Int. with scholia. Some of these are attributed to Olympiodoros, one to Michael of Ephesos. A few scholia derive from 〈Michael Psellos, In Int. paraphrasis〉 and many are closely related to Ammonios' and Stephanos' commentaries. (ff. 75r-192v) Anal. Pr. with abstracts from Ioannes Philoponos' and Ps.-Philoponos' commentaries on Anal. Pr. I and II respectively, as well as abstracts from an anonymous commentary containing an interpolated, earlier version of Leon Magentenos' scholia (for the comments on book II see ff. 147r-192v). (ff. 193r-264r) Anal. Post. with scholia. (ff. 265r-399v) Top. with scholia mostly on books VI-VII. (ff. 400r-441r) Soph. El. with 〈Leon Magentenos'〉 commentary (excerpts); in the margins of ff. 440v-441r and on f. 441v an excerpt from Michael Psellos, 〈Eic $\tau \grave{o}$

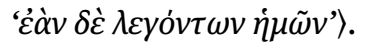

Blank folia: 264v, 299v, 328v.

Secondary Literature (indicative): Stornajolo 1895, 41-43; Ross 1957, 87-92; Minio-Paluello 1964, v-ix; Brunschwig 1967, passim; Follieri 1969, 28-32; Harlfinger 1971, 43 (3), 49; Follieri 1973-74; Tarán 1978, xxv-xli; Ebbesen 1981b, III, 71, 75, 289; Williams 1984, passim; Share 1994, passim; Brockmann 2004, 51; Moore 2005, 161; Rashed 2005; Ebert - Nortmann 2007, 176-178; Brunschwig 2007, passim; Weidemann 2014, ix-x et passim; Agiotis 2015, 3, 19-47; Valente 2018, 112-113; Valente 2021a; Pinakes (link on p. XXIII); DVL (link on p. XXII).

\section{Vind. Phil. gr. 208 (= L)}

Second half of 15th c. paper mm 215/220x150/155 ff. I, 144

Contents: (ff. 1r-8v) Georgios Gemistos Plethon, De virtutibus. (f. 9rv) Plethon, De differentiis (excerpt). (ff. 9v-16r) Xenophon, De republica Lacedaemoniorum. (ff. 17r-115r) 〈Philoponos 2〉, In Anal. Pr. (see p. XLIX). Comments on book I: ff. 17r100r, 111rv, 112v, 114r-115r; the prooimion by (Leon Magentenos) on book II: f. 101r; comments on book II: ff. 101v-110v, 113r. (ff. 116r-120v) (Libanios〉, Declamationes (n. 28). (ff. 121r-122v) Notes concerning calendar issues. (ff. 123r-134) Galen, In Hippocratis librum de victu acutorum (excerpts).

Blank folia: 16v, 100v-100/4r, 112r, 113v-113/3v, 115v-115/2r, $135 \mathrm{rv}$.

Secondary Literature: Hunger 1961, 317; Stefec 2013, 224-225; Pinakes (link on p. XXIII). 


\subsection{Printed Editions}

\section{Trincavelli’s Editio Princeps $(=\mathrm{t})$}

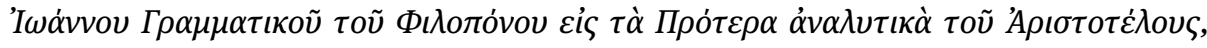

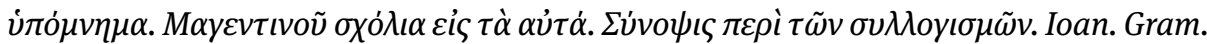
Philoponi comentaria (sic) in Priora analytica Aristotelis. Magentini comentaria in eadem. Libellus de syllogismis. Privilegio Senatus Veneti cautum est, nequis hosce libros per decennium impune, aut imprimat, aut alibi impressos in hac civitate, vel aliis Veneto imperio subditis vendat, MDXXXVI. ${ }^{17}$

Contents: (ff. IIIr-LXXXXIIIIv) Ioannes Philoponos, In Anal.Pr. I (ff. LXXXXIIIIvCXIXv) Ps.-Philoponos, In Anal. Pr. II （ff. Ir-XXXXIv) Leon Magentenos, In Anal. Pr. (ff. XXXIr-XXXXIr: the comments on book II). (ff. XXXXIIr-XXXXVv) The last sec-

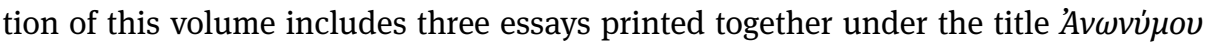

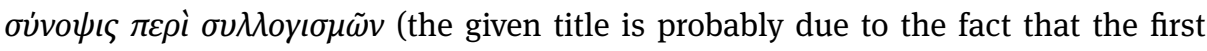

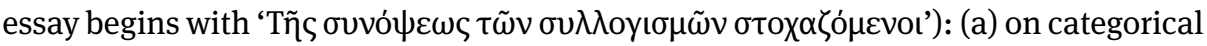
syllogisms (ends in f. XXXXIIIIv.18); on hypothetical syllogisms (ends in f. XXXXVr.9 and is followed by a table presenting six kinds of hypothetical syllogisms); (b) again on the categorical syllogisms (ends in $\mathrm{f}$. XXXXVv). The first essay is in some cases ascribed to either Georgios Choiroboskos, or Michael Psellos, ${ }^{18}$ whereas Laur. 71.33, ff. $145 \mathrm{v}-146 \mathrm{v}$ transmit a slightly shorter version of the text on the hypothetical syllogisms under the name of Magentenos. ${ }^{19}$ The fact that all three essays were edited together must be a reflection of the manner in which they were copied in the manuscript that Trincavelli used for his edition.

\section{Rasari’s Translation into Latin $\left(=\mathbf{r}^{1}\right)$}

Magentini in Priores Aristotelis resolut. explanatio Ioanne Baptista Rasario interprete. Cautum Privilegiis, Summi Pontificis, ac illustrissi Senatus Veneti, nequis hunc librum in aliquo suae diotiones loco imprimat, aut alibi impressum vendere audeat. Venetiis apud Hieronymum Scotum, MDXXXXIIII. ${ }^{20}$

Contents: Anal. Pr. II alternating with the commentary by Leon Magentenos on pp. 47-67, in two columns.

17 Editorial note on f. XXXXVv: 'Venetiis in aedibus Bartholomaei Zanetti Casterzagensis, aere vero, et diligentia Ioannis Francisci Trincavelli. Anno a partu Virginis. MDXXXVI. Mense Aprili'. See the digitised copy of $M D Z$ (link on p. XXII). On Marc. gr. 231 and 235 as possible templates for Philoponos' text in this edition, see Wallies 1905, xxiii-xiv and Sicherl 1993, 58-61 respectively.

18 Moore 2005, 248-249, PHI.20.

19 See p. XXVIII.

20 See the digitised copy of $M D Z$ (link on p. XXII). 


\section{The Second Edition of Rasari's Translation $\left(=r^{2}\right)$}

Ammonius in Porphyrii institutionem. Magentinus in librum Aristotelis De interpretatione. Magentinus in Priora analytica Nili De ratiocinationibus libellus. Georgii Pachymerii Epitome in universam Aristotelis artem differendi. Ioanne Baptista Rasario interprete. Ex eiusdem interpretis recognitione. Lugduni apud Sebastianum Gryphium, MDXLVII. ${ }^{21}$

Contents: (pp. 3-54) Ammonios, In Porph. Isag. (pp. 55-102) Ps.-Magentenos (?), In Int. ～(pp. 103-226) Anal. Pr. alternating with the commentary of Leon Magentenos (pp. 188-226: book II). (pp. 227-261) Georgios Pachymeres, In Arist. Organon paraphr. (pp. 262-270.2) The Latin translation of a brief treatise On Syllogisms attributed to Neilos Kabasilas. ${ }^{22}$ (pp. 270.3-278) A short essay on the Organon (Porphyrios' Isagoge, Cat., Int., Anal. Pr. I 2-6, Soph. El.) which was printed together with Kabasilas' work.

\subsection{The Text's Genealogy}

\section{The Direct Tradition: Hyparchetypes V and D}

Manuscript $\mathrm{V}$ is written on oriental paper folded in quarto; ${ }^{23}$ the codex is traditionally dated to the thirteenth century (see p. XXXIV). As for systematic presentation of palaeographical features, however, Herbert Hunger points towards similarities between the second ductus of the scribe ${ }^{24}$ and that of state documents in the eleventh century, ${ }^{25}$ and dates the codex to the twelfth century. ${ }^{26}$ Furthermore, Guglielmo Cavallo has highlighted the bureaucratic connotations of the script in the codex ('scritture ...ricche di connotazioni burocratiche') and so also dated it to the twelfth century. ${ }^{27} \mathrm{We}$ may add that hands similar to V can be found in Vat. gr. 65 (before 1063), Vat. Barb. gr. 369 (end of 11th c.), ,8 Vat. gr. 504 (1105), ${ }^{29}$ Vat. gr. 586 (1124), ${ }^{30}$ Laur. 74.18 (scribe Ioan-

21 See the digitised copy of $M D Z$ (link on p. XXII).

22 See p. LVIII.

23 Later additions of western-paper folia are only few and easy to distinguish; e.g. the binio at the end of the codex (ff. 297-300) bearing a watermark similar with Briquet 1977, n. 6292 (1509/10). For the characteristics of the oriental paper see Irigoin 1950, 134-136.

24 See ff. 521v main text of Top. and i. m. ext., scholion $\rho \kappa \varepsilon^{\prime}, 1.15-522 \mathrm{v}, 530 \mathrm{v}$ i. m. ext., scholion $\rho \pi \theta^{\prime}$ $-531 \mathrm{v}$.

25 Hunger 1990-91, 34.

26 Hunger 1991, 74-75.

27 Cavallo 2000, 232.

28 Canart - Perria 1991, 79; Cavallo 2000, 231.

29 I am thankful to Inmaculada Pérez Martín for drawing my attention to the codex Vat. gr. 504 and for suggesting that V might be dated to the Komnenian period. See also Canart - Peria 1991, 80-81, 101; RGK III, n. 313; Canart 1998, t. 38 n. 53.

30 Devreesse 1937, 512-513; RGK III, n. 460. 
nikios; second quarter of the 12th c.) ${ }^{31}$ and Vat. gr. 1903 (end of 12th c.?). ${ }^{32}$ Therefore further palaeographical investigation is required to resolve the question of V's dating.

V transmits overall better readings than D (see below p. LXIV) and probably contains the whole of the commentary on Anal. Pr. II. ${ }^{33}$ The text layout of the Vatican manuscript is characterised by its symmetry. ${ }^{34}$ The scribe leaves a few folia empty before each treatise of the Organon. ${ }^{35}$ This he does in order to later add the corresponding prooemia or introductory material. He always attempts to adequately arrange the space left for scholia on a given passage. ${ }^{36}$ The second ductus, which was mentioned above, is principally employed for editorial interventions which occur throughout the codex. Specifically, these are corrections of the main text, ${ }^{37}$ additional marginal scholia (which were afterwards inserted in the main text of the commentary in the descendants of V) ${ }^{38}$ and diagrams. ${ }^{39}$ Magentenos' comments are copied onto the upper, lower and outer margins of the Organon, to which Greek numbers are supplied, connecting them with the text. The enumeration of scholia was carried out by the copyist himself as is occasionally implied in his notes ${ }^{40}$ and corrections. ${ }^{41}$ Moreover, there are comments whose Greek numbers are not added in the Aristotelian text, ${ }^{42}$ scholia numbered by later hands ${ }^{43}$ as well as omissions or repetitions of numbers. ${ }^{44}$ At any rate,

31 Bandini 1770, 120-121; RGK II, n. 283; Cavallo 2000, 232. On Ioannikios see Wilson 1983; Brockmann 2008. On the date of his activities see Vuillemin-Diem Rashed 1997, 176-178.

32 Cavallo 2000, 232; cf. Canart 1970, 615-616; Canart - Perria 1991, 81.

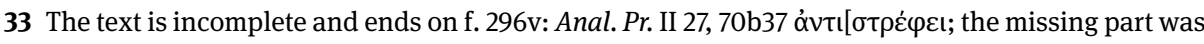
added by a later hand on $\mathrm{f}$. 297r.

34 Ebbesen 1981b, I, 314-316.

35 As regards the text of the Top. in V, Brunschwig 2007, XLVIII (82) suggests that Par. Coisl. 330 was most likely the exemplar of $\mathrm{V}$. On the exegetical material used by the scribe in the case of the Anal. Post. see Brockmann 2019, 220-221; Valente 2021a.

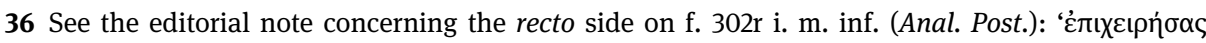

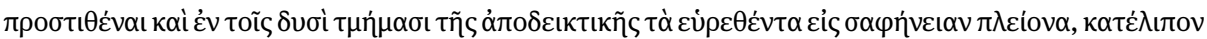

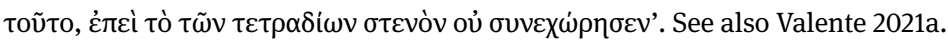

37 For Anal. Pr. II see ff. 255r s.1. 15, 258r s.l. 3.

38 For Anal. Pr. II see ff. 253v, 256r, 258r, 259r, 262r, 263rv, 277r, 279r, 281v, 282v, 285rv, 288v, 290v, 291r-292v, 294rv.

39 For Anal. Pr. II see ff. 241v-242v, 246v-247r, 253v-255v, 259r, 263v, 269v, 274v, 281rv, 282v, 285r, 291rv, 294v.

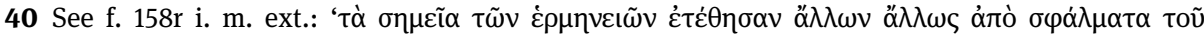

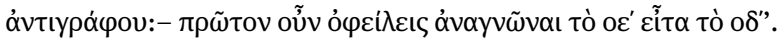

41 On f. 160v i. m. inf., for instance, at the end of scholion $\pi^{\prime}$, the scribe erases a few words and then copies them on the upper margin of $f .161$ as the beginning of a new scholion with the number $\pi \alpha^{\prime}$. See also the refererences to inconsistencies or different layers of commenting in the two hyparchetypes on p. LXV.

42 Comments 83, 88, 89, 91, 92, 96, 117, 124, 141, 157, 170, 172, 188, 226.

43 Comments 49, 50, 51, 70, 73, 123, 192, 193, 194.

44 The scribe omits numbers o $\zeta^{\prime}$ and $\rho \circ \zeta^{\prime}$ of Anal. Pr. I and II respectively, whereas the scholia o'-oø ' of the first book (ff. 163-166) should have been numbered $\rho^{\prime}-\rho \sigma \tau^{\prime}$. 
the numbering of Magentenos' scholia in the Vatican manuscript does not always follow the same pattern. Sometimes numbering is introduced according to books or even smaller sections. On other occasions, enumeration runs sequentially through whole treatises, from beginning to end. ${ }^{45} \mathrm{~A}$ second layer of additions ${ }^{46}$ is attached to the Aristotelian text by means of various reference symbols. ${ }^{47}$

Alexios Solymas finished copying D on 15th July 1272 according to the colophon on $\mathrm{f} .203 \mathrm{r} .{ }^{48}$ It seems that the codex was later to the possession of Ioannes Chortasmenos. ${ }^{49}$ Solymas makes no effort to distinguish between what belongs to Magentenos and what does not. In many cases, the scribe does not even take the trouble to mark the beginning or the end of a given scholion. He did, however, intend to add many of the initial letters later, since he occasionally left space for that purpose. Whenever they are added, the initial letter are copied with red ink. Magentenos' commentary is copied in D anonymously and is incomplete. ${ }^{50}$ There are more diagrams attached to the scholia than in V (see p. LXXXIX).

In some cases the text in $\mathrm{V}$ has been augmented (or simplified in $\mathrm{D}$ ):

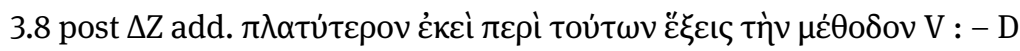

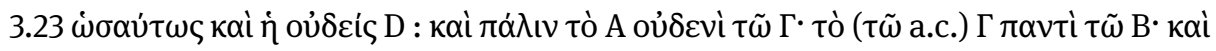

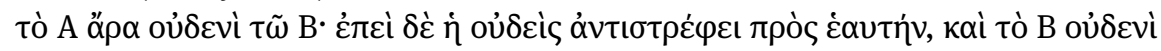

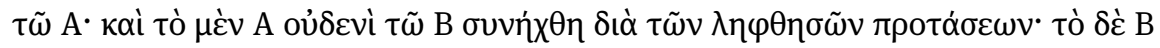

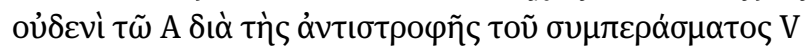

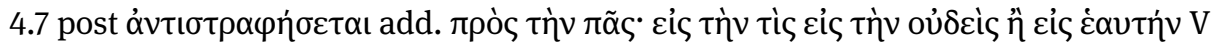
$:-\mathrm{D}$

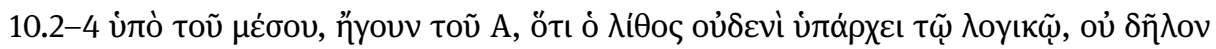

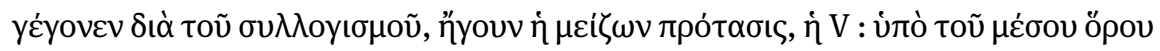

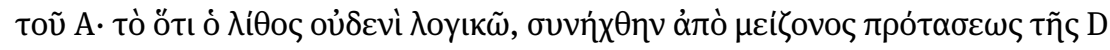

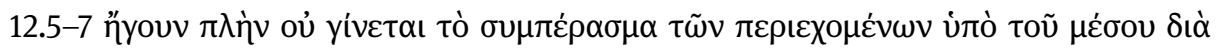

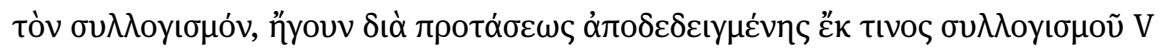

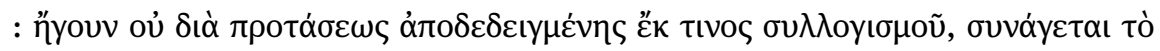

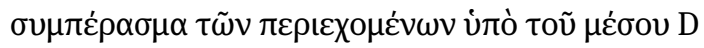

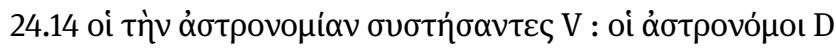

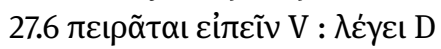

45 See Mercati - Franchi de’ Cavalieri 1923, 313-317.

46 Many of these comments derive from the commentary written by Ps.-Philoponos, In Anal. Pr. II.

47 On reference marks in Greek manuscripts see e.g. Atsalos 1991, 211-231; McNamee 1992, 28-48; Agiotis 2016; Valente 2021b.

48 Turyn 1972, I, 22-23; II, 222c, d; below p. 205.

49 Turyn 1972, I, 23.

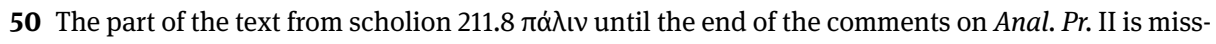
ing. The possibility that $\mathrm{D}$ transmits a shorter version of the commentary should be excluded. There follows no analysis of positive syllogisms, although they are mentioned beside hypothetical syllogisms at the beginning of the scholion (schol. 211.2). 


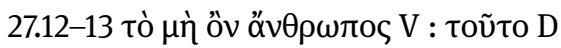

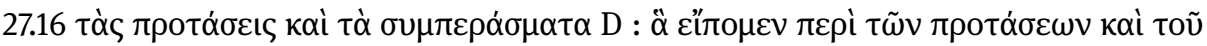

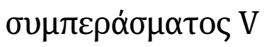

$30.5 \pi \varepsilon \iota \tilde{\alpha} \tau \alpha \iota ~ \delta \varepsilon \tilde{\zeta} \alpha \iota \mathrm{V}: \delta \varepsilon i ́ \kappa v v \sigma ı \mathrm{D}$

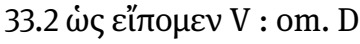

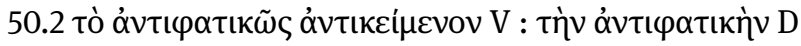

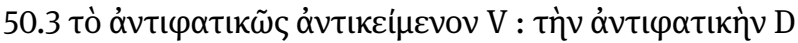

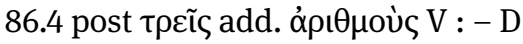

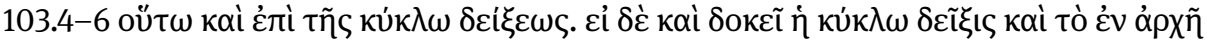

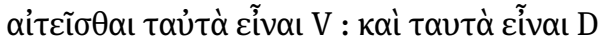

Similar augmentations are also true for the text in D:

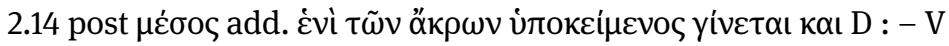

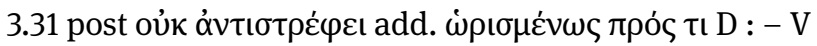

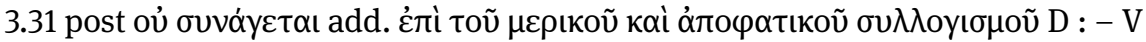

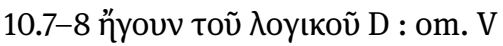

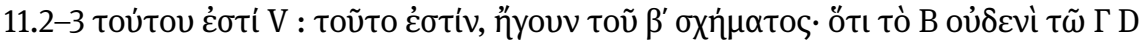

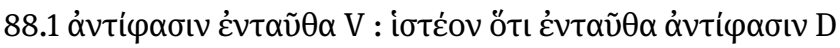

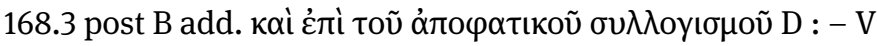

It can be concluded that $\mathrm{V}$ and $\mathrm{D}$ share a common ancestor as is indicated by the following conjunctive errors in scholia which are not transmitted by the interpolated version of Magentenos' commentary in U (see p. LXXIII):

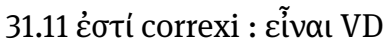

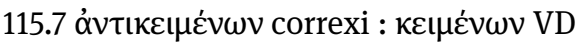

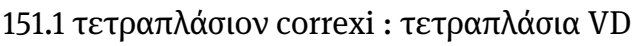

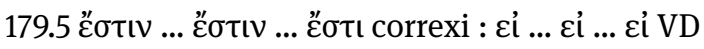

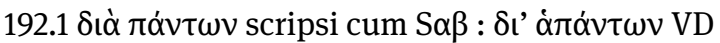

There are also variants in $\mathrm{V}$ and $\mathrm{D}$ which are similar probably due to their common ancestor:

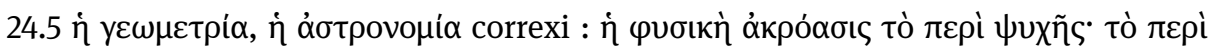

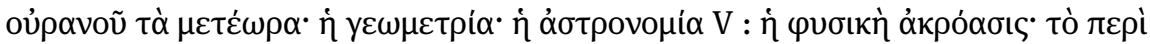

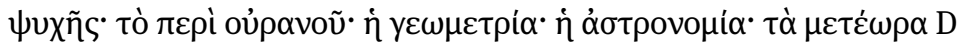

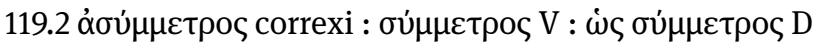

The two texts are independed of each other. There are 'saut du même au même' errors (homoeoteleuta) in $\mathrm{V}$ when compared to the correct readings in $\mathrm{D}$ :

10.1-2 ท’youv - $\mu \varepsilon \dot{\sigma o u} \mathrm{D}:$ om. V

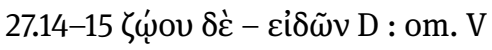

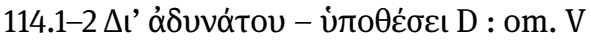

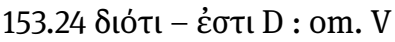


Similarly, there are errors (homoeoteleuta / homoeoarcton*) in D when compared against correct readings in $\mathrm{V}$ :

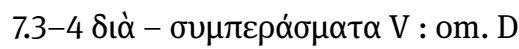

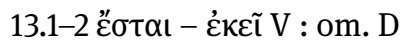

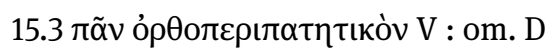

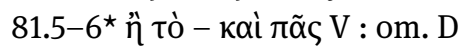

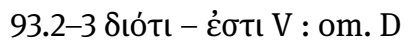

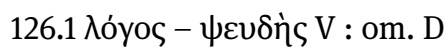

150.3-5 oủ X - ywvíac V : om. D

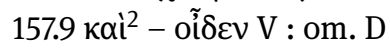

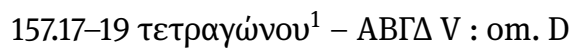

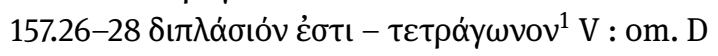

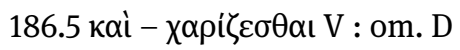

Furthermore, there exists a special category of variants. Clearly, owing to inconsistencies or different layers of commenting that already existed in the archetype, the sequence of scholia in both hyparchetypes does not always correspond to the passage order within Anal. Pr. II.

There are four types of such inconsistencies (see also p. LXXXI):

- Scholia or glosses with the same, but wrong sequential position in V ante correcturam and D. The scribe of V sometimes recognised the errors. Although he initially recorded that some of these scholia belonged to Magentenos' text (that is, he gave them Greek numbers), he then corrected himself by erasing the scholia at their original location and rewrote them in margine or inter lineas in their proper place. In most cases, he 'reattached' the scholion to the Aristotelian text by using a symbol instead of a number (see above p. LXII).

- Scholia forming a single item in V ante correcturam and/or D.

- Scholia or glosses with different sequencing in $\mathrm{V}$ and $\mathrm{D}$.

- Scholia or glosses omitted in either V or D.

Table 1 includes a specimen (comments 135-150; see p. LXVI) of the scholia clutter that exists in both $\mathrm{V}$ and $\mathrm{D}$, as well as its evolution in the later manuscript tradition. At the same time, the arrangement in Table 1 may function as a preliminary account of the relations between manuscripts. 
LXVI 3 The Transmission of Magentenos' Commentary on Anal. Pr. II

Table 1: Sequence of scholia 135-150

\begin{tabular}{|c|c|c|c|c|c|c|c|}
\hline V a.c. & V p.c. & $\mathbf{S}$ & $\mathrm{FE}$ & K & PYM & $x$ & $\operatorname{Dtr}^{1} r^{2}$ \\
\hline 135 & 135 & 135 & 135 & 135 & 135 & 135 & 135 \\
\hline a3 & $\star \star 136$ & 138 & 138 & 138 & 138 & 135 & 140 \\
\hline 140 & *138 & 141 & 141 & 141 & a1 & 143 & 143 \\
\hline a5 & $\star \star 139$ & a3 & a3 & 147 & 141 & a8 & 144 \\
\hline a6 & *141 & a5 & 140 & 148 & a3 & 144 & 146 \\
\hline 143 & a3 & $a 6$ & a5 & 149 & a4 & 145 & 148 \\
\hline 144 & 140 & 140 & $\mathrm{a} 6$ & 140 & a7 & 146 & 149 \\
\hline 145 & a5 & 143 & 143 & a3 & a5 & 148 & 147 \\
\hline 146 & $\mathrm{a} 6$ & 144 & 144 & a5 & $\mathrm{a} 6$ & 149 & 136 \\
\hline 148 & 143 & 145 & 145 & 143 & 140 & 150 & 137 \\
\hline 149 & 144 & 146 & 146 & a6 & 143 & & 138 \\
\hline a8 & 145 & 147 & 147 & 144 & a8 & & 139 \\
\hline 147 & 146 & 148 & 148 & 145 & 144 & & 141 \\
\hline 136 & *147 & 149 & 149 & 146 & 145 & & a3 \\
\hline 137 & 148 & a8 & $\mathrm{a} 8$ & 150 & 146 & & a5 \\
\hline 138 & 149 & 150 & 150 & & 148 & & a6 \\
\hline 139 & $\mathrm{a} 8$ & & & & 149 & & a2 \\
\hline 141 & 150 & & & & 150 & & a8 \\
\hline \multicolumn{8}{|l|}{150} \\
\hline \multicolumn{8}{|c|}{${ }^{\star}=$ in margine $;{ }^{\star \star}=$ inter lineas; a1-8 = glosses attached to Leon's comments } \\
\hline \multicolumn{8}{|c|}{ a1 = on Anal. Pr. II 21, 66b23 عi - $24 \mu \eta \delta \varepsilon v i ́$} \\
\hline \multicolumn{8}{|c|}{ 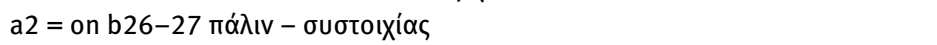 } \\
\hline \multicolumn{8}{|c|}{$\mathrm{a} 3=$ on b27-28 oĩov $-\tau \tilde{\text { c̣ }} \mathrm{B}$} \\
\hline \multicolumn{8}{|c|}{ 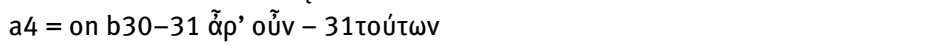 } \\
\hline \multicolumn{8}{|c|}{ 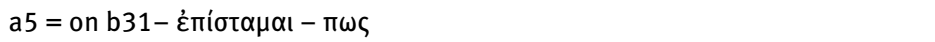 } \\
\hline \multicolumn{8}{|c|}{$a 6=$ on b33 ö $\pi \omega \varsigma$} \\
\hline \multicolumn{8}{|c|}{ 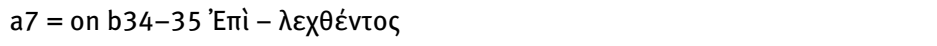 } \\
\hline \multicolumn{8}{|c|}{ a8 $=$ on $67 \mathrm{a} 8$ ò $\mu$ oí $\alpha-\dot{\alpha} \pi \alpha \dot{t} t \eta$} \\
\hline
\end{tabular}

\section{The Descendants of $\mathbf{V}$}

\section{Manuscript S}

S and Par. Coisl. 170 were copied by the same scribe and might together have comprised a single edition of Magentenos' commentaries on the Organon. ${ }^{51} \mathrm{~S}$ has been occasionally supplemented with section titles or lemmata, but overall it is an excellent copy of $\mathrm{V}$. The text in $\mathrm{S}$ bears none of the errors in the rest of the direct tradition (manuscripts FEK, PYMR, X; see below), whereas it transmits all the errors of $\mathrm{V}$ beside its own separative errors:

$3.26 \mathrm{~B}^{1} \mathrm{~V}$ : om. S

3.29 uóvov $\mathrm{V}: \mu \varepsilon \dot{v o v} \mathrm{~S}$

51 See Ebbesen 1981b, III, 75-76. 


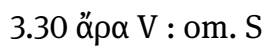

70.1-2 ع́vavtíov iter. $\mathrm{S}$

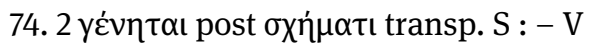

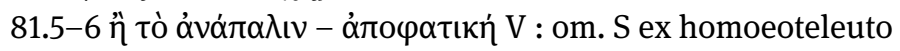

$94.1 \mu$ ทे V : om. S

145.9 ćvavtíov V : om. S

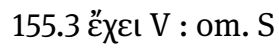

\section{$\alpha$ and Manuscripts FEK}

The dependance of FEK on $\mathrm{V}$ through an intermediary common ancestor has been suggested by eminent scholars in previous editions of Magentenos' commentaries. ${ }^{52}$ As one of them remarks, the scribe of $\alpha$ 'very rarely commited an error' ${ }^{53}$ It is indeed so; I was able to assume the existence of $\alpha$ on the basis of the following readings (on manuscripts $\beta$ [= PYMR] and $X$ see below).

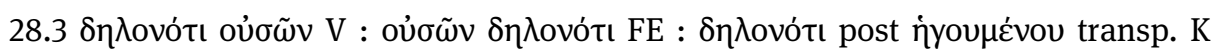
( $\delta \eta \lambda$ ovótı must have been supplemented supra lineam in $\alpha$ )

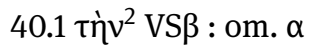

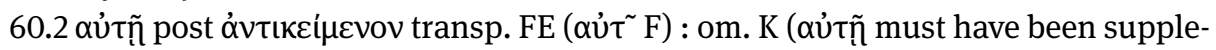
mented supra lineam in $\alpha):-\mathrm{VS} \beta$

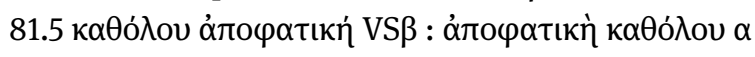

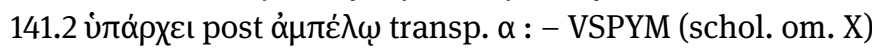

153.19 นo $\tilde{v}^{2}$ VSPYM (schol. om. R) : om. $\alpha$ : deest in X

176.6 nैyouv VS $\beta$ : om. $\alpha$

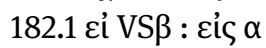

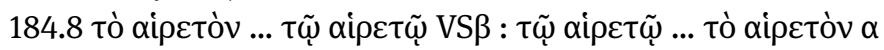

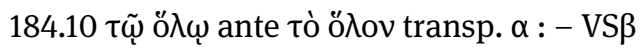

That being said, the dependance of $\mathrm{E}$ on $\mathrm{F}$ and the provenance of both $\mathrm{F}$ and $\mathrm{K}$ from $\mathrm{V}$ can be confirmed in the case of the commentary on Anal. Pr. too. The main text and comments in $\mathrm{K}$ were copied by two different scribes working together (see, for instance, f. 203v) probably towards the end of the fourteenth or the beginning of the fifteenth century.54 At the beginning of Anal. Pr. II, the second scribe copies scholia by Ps.-Philoponos, which he then mingles and eventually replaces with Magentenos' own work (scholia 21-227 with omissions; some of them are due to scholia missing

52 Ebbesen 1981b, III, 76-78 and Kotzabassi 1999, 52-56 where this text bears the siglum 'p'. See also Brockmann 2019, 222; Valente 2021a.

53 Ebbesen 1981b, III, 76.

54 This can be attested by examining of the watermarks. On the watermarks of ff. 13, 31 see Mošin Traljić 1957, n. 1968 (1393). Mošin - Traljić 1957, n. 1072 (1385/1400) is very similar to the watermark of f. 22. 
from V). The copyist also employed this method in other works in K as well. ${ }^{55}$ Further, $\mathrm{K}$ transmits errors when compared to correct readings of $\mathrm{FE}$ :

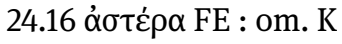

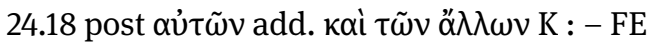

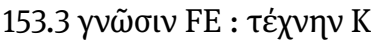

153.28 post $B^{2}$ add. ő $\lambda \omega \mathrm{K}:-\mathrm{FE}$

$160.2 \mathrm{~B}^{2} \mathrm{FE}: \mathrm{A} \mathrm{K}$

161.1 oûv $\mathrm{FE}:$ yoũv $\mathrm{K}$

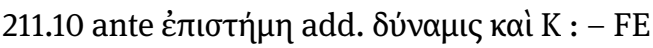

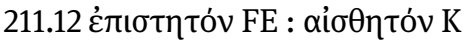

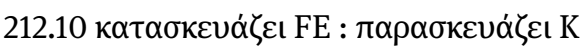

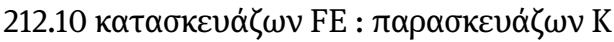

Beside strikingly similar layout with F, E transmits separative errors not found in F (and K):

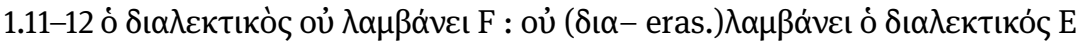

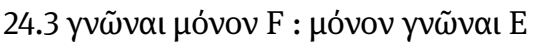

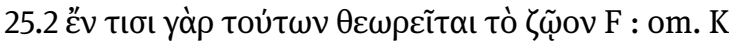

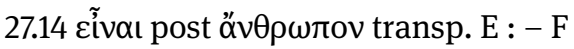

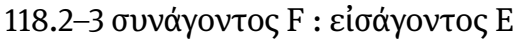

121.6-7 عỉ $\delta \dot{\varepsilon}-\alpha \dot{\delta} \delta$ vatov iter. E

127.14 ò $\varepsilon \rho \omega \tau \tilde{\omega} \nu$ post $\mu \varepsilon \dot{\lambda} \lambda \varepsilon$ เ transp. E : - F

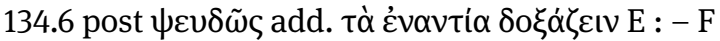

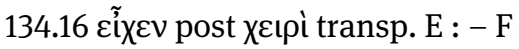

$153.28 \pi \alpha v \tau i$ ante $\tau \tilde{\omega} \Gamma$ transp. $\mathrm{E}:-\mathrm{F}$

I was not able to find any separative errors in $\mathrm{F}$ with regard to the respective correct readings in $\mathrm{K}$. A dependance of $\mathrm{K}$ on $\mathrm{F}$, however, should be excluded because of the different sequential position (and omissions) of scholia in the two manuscripts (see p. LXVI, Table 1).

Finally, there are additional errors in $\mathrm{F}$ (and $\mathrm{E}$ ) against the correct readings of $\mathrm{V}$ (and the rest of the tradition). Nevertheless, there is no way to tell whether these errors were originally commited in $\mathrm{F}$ or $\alpha$, since $\mathrm{K}$ does not transmit the respective scholia.

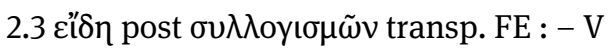

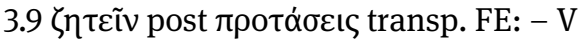

7.5 ह้นعрov V : om. FE

55 Ebbesen 1981b, III, 77. 


\section{$\boldsymbol{\beta}$ and Manuscripts PYMR}

PYMR transmit the errors contained in V, but the separative errors of $\alpha$ or S (or X; see below). The manuscripts PYR are related with the editorial work of Neophytos Prodromenos (second half of 14 th c.) ${ }^{56}$ and share similar features, notably text layout, ornamental elements and diagrams.

The omission of scholia $36,147,165,199$, as well as the following conjunctive errors in PYMR indicate that $\beta$ is their common ancestor.

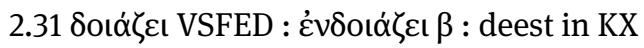

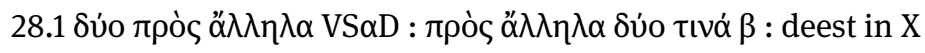

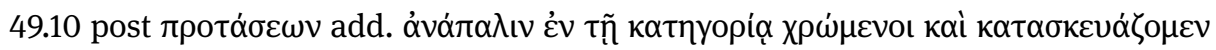
$\tau \grave{\eta} \nu \dot{\varepsilon} \tau \varepsilon \dot{\rho} \rho \nu \beta$

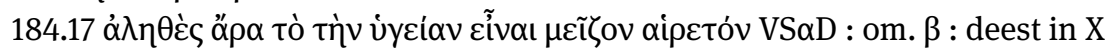

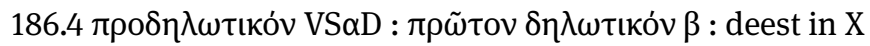

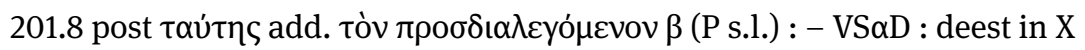

It seems that the text in $\beta$ has occasionally been slightly augmented or syntactically modified. A few examples (beside $\beta$ are mentioned only manuscripts which transmit the following scholia):

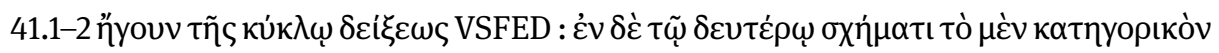

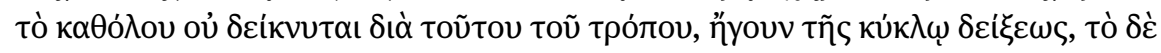

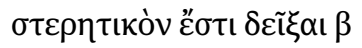

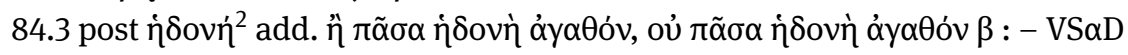

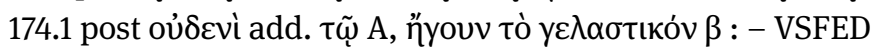

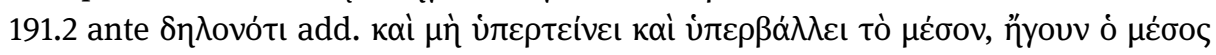
öpos $\beta$ : - VS $\alpha \mathrm{D}$

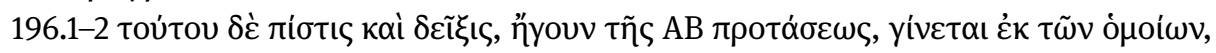

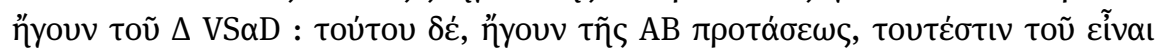

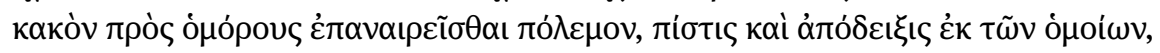

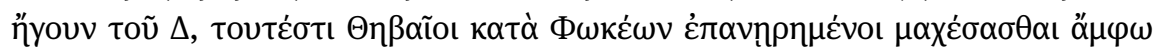
$\delta ı \varepsilon \varphi \theta \dot{\rho} \eta \sigma \alpha \nu \beta$

Later additions of scholia in the margins of $\mathrm{V}$ are usually noted by means of the indication ' $\sigma \chi 0$ ó $ı$ ıv' in the margins of PYR. R may be dated later than PY, ${ }^{57}$ it omits large chunks of the commentary and contains repetitions of text: e.g. (a) scholia $117.4 \tau \tilde{\eta} \mathrm{S}$

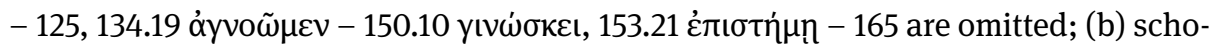
lion 112 was copied twice (ff. 336rv and 343v; in the latter case the text ends at 112.5 $\kappa \alpha i^{2}$ ). Titles and lemmata in R are much shorter than in PYM. Diagrams in R's margins are drawn less carefully than in the case of PY. The close relation of PYM to each

56 Cacouros 1998, 187-95; Mondrain 2000, 13-14, $16-17$.

57 See the watermark of f. 33 which is very similar to Briquet 1977, n. 7369 (1424). 
other, as well as the independence of PYM and R from one another are evident from the following readings too.

Separative errors of $\mathrm{R}$ against correct readings of PYM:

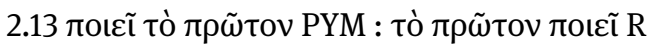

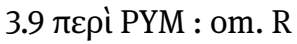

$7.4 \pi \lambda$ cíova PYM : om. R

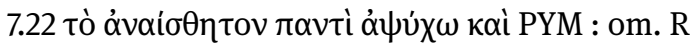

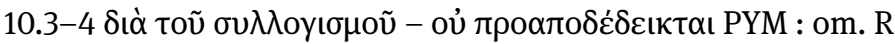

$27.1 \delta ı$ เ $\dot{\xi} \alpha \varsigma$ PYM : $\delta \varepsilon \dot{\xi} \xi \alpha \varsigma \mathrm{R}$

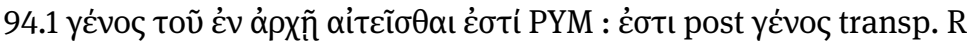

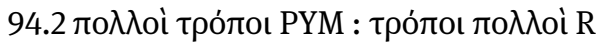

Separative errors of PYM against correct readings of R:

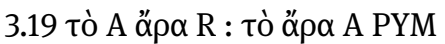

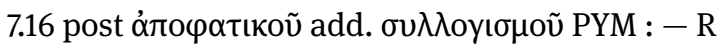

D. Reinsch has already demonstrated that the Parisinus was used as the template for the Vaticanus. ${ }^{58}$ From P's watermarks it can be inferred that it was probably copied towards the end of the fourteenth century. ${ }^{59} \mathrm{Y}$ exhibits the errors of $\mathrm{P}$ and has its own separative errors, which are to be found also in $\mathrm{M}$.

Examples of errors of YM against correct readings of $\mathrm{P}$ ( $\mathrm{R}$ omits the relevant scholia) and a couple of supra lineam additions in $\mathrm{P}$ which were later inserted in the text of YM:

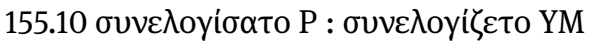

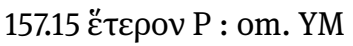

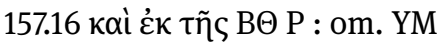

153.30 ante $\tau \tilde{\omega} \dot{\varepsilon} \xi \omega \gamma \kappa \omega \mu \varepsilon \dot{v} \eta v$ add. $\tau \tilde{\omega} \Gamma$ P s.l., YM

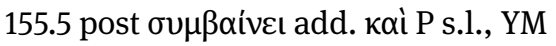

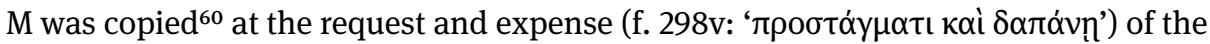
diplomat and humanist Albertus Pius (1475-1550). As for Magentenos' scholia, M contains the same text as PY, but not the diagrams or the Anal. Pr. Separative errors of M against correct readings of $\mathrm{Y}$ :

134.19 oíov $\mathrm{Y}$ : ốos $\mathrm{M}$

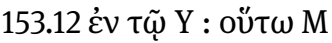

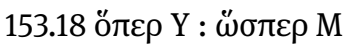

58 See the online description of the CAGB Database (link on p. XXIII).

59 Briquet 1977, n. 797 (1390/99) is very similar with the watermark of the ff. 159, 161, 163-165, 167, 172, $178,180$.

60 De Gregorio - Eleuteri 1993, 159 suggests that the same scribe copied Mut. gr. $\alpha . V .6 .5$ (198), 104r-115r and Vat. Ott. gr. 76 from f. 219r. 


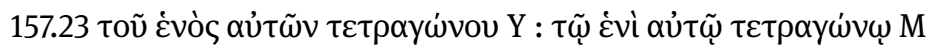

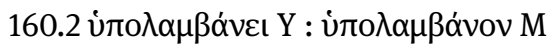

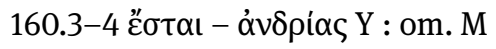

A few common or obviously related readings between $\mathrm{D}$ and $\beta$ may indicate interpolation in $\beta$.

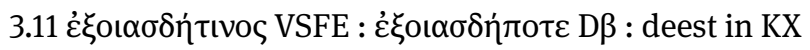

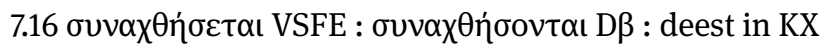

7.20 ő $\alpha \mathrm{D} \beta$ : om. VSFE : deest in KX

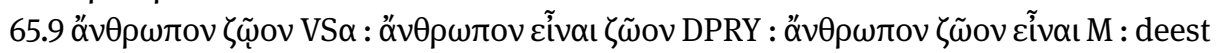
in $\mathrm{X}$

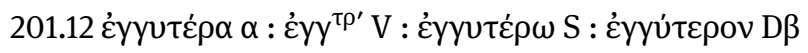

\section{Manuscript X}

$\mathrm{X}$ transmits chapters VII-XI with omissions. It exhibits the same errors as V and has its own separative errors. The most critical of the separative errors, however, is the omission of scholia present in two facing folia in V (ff. $280 \mathrm{v}-281 \mathrm{r}=134.19$ oíov -141 ). We may therefore infer that $\mathrm{X}$ depends on $\mathrm{V}$.

\section{D, the Editio Princeps and the Latin Translation of the Commentary on Anal. Pr. II}

The works of Leon Magentenos stirred the interest of editors many times during the sixteenth century. Within a period of just 44 years a commentary on Int. ascribed to Magentenos was published five times, while his commentary on the Anal. Pr. three times (see also pp. XXVII, XXIX). This remarkable editorial activity was in all probability due to the philosophical debate among Aristotelians in Padua in this period. ${ }^{61}$ At any rate, the text of the first edition of the commentary on Anal. Pr. by Vittore Trincavelli (1496-1568) was reliant on the text of the Ambrosianus, since the former transmits all the errors of the latter. The editor intervenes only to add the author's identity, the title of the commentary and occasionally section titles, lemmata and insignificant corrections.

Fewer than 10 years later, Giovanni Rasari (1517-1578) did not hide his enthusiasm when translating the Greek edition into Latin (Venice 1544). ${ }^{62}$ The translation of both texts (Anal. Pr. and commentary of Magentenos) is printed in two columns, with the two texts alternating within a given column.

Here follow the beginning and the end of the editio princeps of Magentenos' comments on Anal. Pr. II, as well as their first translation into Latin:

61 Randall 1940, 177-206 (especially 192-195).

62 See the note of $r^{1}$, misplaced folio between ff. 4 and 5: nescio quo bono fato in Magentini in eum librum explanationem incidi. On this edition, see Shiel 1998, xlix. 
Inc.:

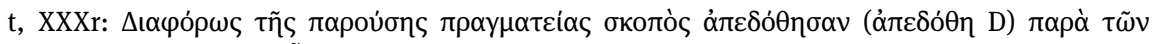

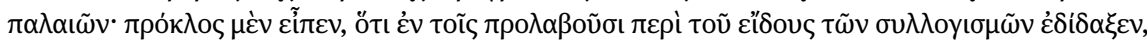

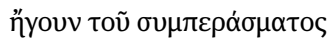

$\mathrm{r}^{1}, 47 \mathrm{r}$ b: Huiusce tractationis argumentum varie, ac dissimiliter veteres interpretes posteris prodidere. Proclus autem inquit in iis, quae ante sunt dicta, forma ratiocinationum, hoc est conclusionem tractata fuisse

Des.:

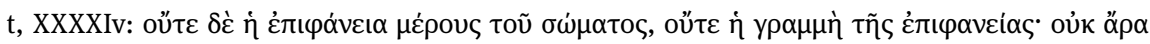

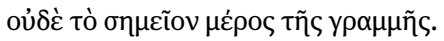

$\mathrm{r}^{1}, 66 \mathrm{v}$ b: sed neque superficies corporis est pars, neque linea superficiei. igitur neque punctum esse lineae partem dicemus.

However, at the end of the translated Aristotelian text on f. $67 \mathrm{v}$ Rasari notes that the Greek text was incomplete by remarking 'Deest explanatio'. The lack of completeness was due to the fact that he used D, itself incomplete (see p. LXIII). This deficiency was remedied three years later. In editorial note in the second edition of the Latin text (Lyon in 1547), the publisher Sebastian Gryphius (ca. 1490-1556) informs the reader that a revised edition of Rasari's collected translations was necessary for scientific and typographical reasons. ${ }^{63}$ The new edition was not printed in columns. Magentenos' text alternated with Anal. Pr., while the missing part of the commentary was replaced by the relevant passages from Philoponos 2 (see p. XLIX).

Here follow the beginning and the end of Greek and Latin texts of the scholia of Philoponos 2 (in manuscript Q), as well as the relevant passages of Ps.-Philoponos on Anal. Pr. II:

\section{First scholion}

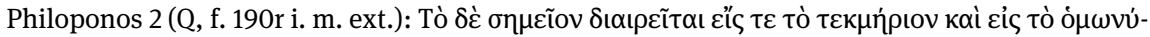

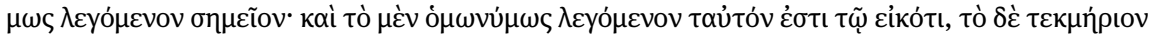
$\mu \varepsilon \tau \dot{\alpha} \alpha \dot{\alpha} \sigma \varphi \alpha \lambda \varepsilon \dot{\alpha} \alpha \varsigma$

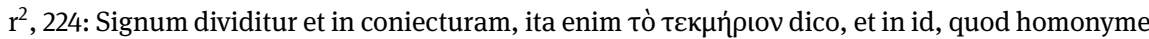
signum dicitur; idque quod homonyme dicitur, idem est quod verisimile. Coniectura vero, sine dubitatione

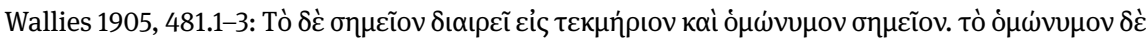

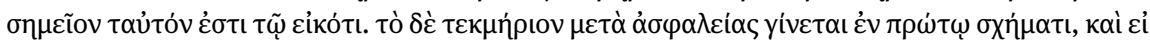

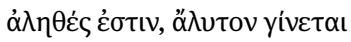

\section{Last scholion}

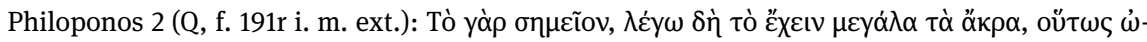

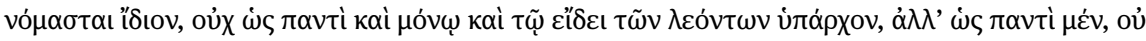

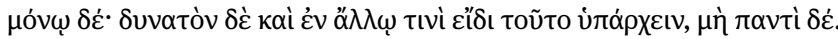


$\mathrm{r}^{2}$, 226: Signum leonum ait esse extremas partes magnas habere; quod proprium nominatum est, non quod toti et soli speciei leonum insit, sed quod omni et non soli conveniat; quippe cum possit etiam in alia quapiam specie inteligi.

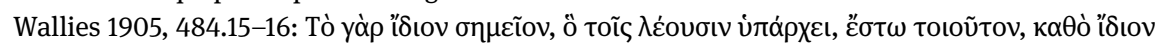

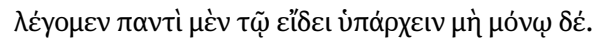

\section{The Indirect Tradition}

\section{Manuscript U}

The famous Vat. Urb. gr. 35 is one of the most important textual-witnesses of the Organon. According to the colophon on f. 441v, the codex was commissioned by the deacon, and later archbishop of Caesarea, Arethas (860 - after 944) and it was copied by the subdeacon Gregorios. Since this note was written by Arethas himself, we may infer that the manuscript was copied before his appointment to the archbishopric of Caesarea, that is, before $902 / 903 . .^{64}$

Two copyists or perhaps one ${ }^{65}$ added two layers of scholia on the Anal. Pr. in the margins around the treatise. Both hands should be dated to the twelfth century, the ductus of scribe B, however, is extremely similar with the one in Vat. gr. 244. I would not exclude the possibility that in both cases the ductus may belong to the same person working during different periods of his life. Scribe A and scribe B in U had at their disposal three sources, (a) abstracts from the commentary of Ioannes Philoponos on Anal. Pr. I, (b) excerpts from the commentary of Ps.-Philoponos on Anal. Pr. II, and (c) a redaction comprising scholia deriving from an interpolated version of Magentenos' commentary and an unknown source. I name the interpolated text of Magentenos in U recensio Urbinatis. ${ }^{66}$ In contrast, I name the text of the present edition recensio vulgata. In the case of Anal. Pr. II, scribe A (dark brown ink) copied Ps.-Philoponos as far as f. 163r, whereas scribe B (light brown ink) filled the margins with the text of the redaction, which he occasionally tried to insert into the text that had already been copied by his colleague (see e.g. ff. 147r, 158v).

The redaction copied by scribe B in the margins of Anal. Pr. II contains a total of 88 scholia, of which 61 belong to the recensio Urbinatis, whereas the remaining 27 are of unknown origin. The comments of the recensio Urbinatis can be divided into six groups:

$\overline{64 P m b Z}$, n. 20554.

65 I am thankful to Dr. Stefano Valente for drawing my attention to the possibility that both ductus might belong to the same scribe.

66 In order to distinguish between the text of the Anal. Pr. and the recensio Urbinatis, we have employed the traditional siglum A for the former and the siglum $U$ for the latter (see p. LXXXIV). 
1. Two scholia in the vulgata $(47,86)$ correspond to two diagrams in the Urbinas. In the case of scholion 47 , the correspondence is only partial. ${ }^{67}$

2. Nine scholia in the Urbinas transmit less text than the vulgata $(1,27,33-35,42,75$, $84,206){ }^{68}$

3. Nine scholia in the vulgata are blended together (major or minor transpositions, different wording, omissions and additions of text, diagrams) so as to form four scholia in the Urbinas (93/102/94; 134/141; 157/152; 184/185). ${ }^{69}$

4. Twenty-eight scholia are to be found almost verbatim in both versions (14, 21, 24, $25,44,48,49,55,57,65-72,78,81,83,85,111,113,146,150,164,194,226)$.

5. Eleven of the comments in the Urbinas transmit more text or partially different wording than the vulgata $(59,90,103,123,127,180,186,187,200,201,221) .^{70}$

6 . Two scholia in the vulgata $(153,205)$ are separated into four comments transmitting more text in the Urbinas. ${ }^{71}$

Could it be that the recensio Urbinatis is derived from a source other than Magentenos, which was then used by him? Had that indeed been the case, then Magentenos would most probably have included in the vulgata at least a few of the additions made in groups 3, 5 and 6. It seems likely that the extra material of the scholia and diagrams in groups 3, 5 and 6 was probably added by another commentator (or other commentators) during an excerpting phase, from which groups 1, 2 and 4 where excluded. This process resulted to an interpolated text, namely the lost $\alpha^{\star}$ (see the stemma on p. LXXIX). As $\alpha^{\star}$ was incomplete, this meant much of Anal. Pr. II was left uncommented upon. Therefore scribe B himself (or possibly even the compiler of $\alpha^{\star}$ ) decided to fill the lacunae by applying a second layer of interpolations, in other words the 31 remaining scholia in the redaction of $\mathrm{U}$. Moreover, the recensio Urbinatis seems to stem from an earlier stage of Magentenos' commentary because of the text in groups 1 and 2, and the fact that the latter text transmits fewer scholia than the vulgata.

Furthermore, there are mistakes in the vulgata when compared to the correct readings in $\mathrm{U}$ :

$70.4 \Gamma \mathrm{U}: \mathrm{B}$ VD

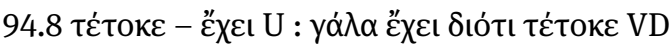

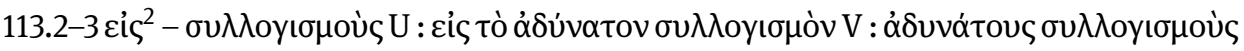

$\mathrm{D}$

$127.4 \pi \alpha \rho \dot{\alpha} \mathrm{U}: \pi \varepsilon \rho \grave{~ V D}$

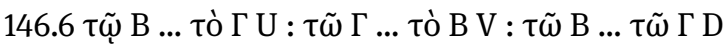

67 See p. 195.

68 See p. 195.

69 See p. 196.

70 See p. 198.

71 See p. 202. 
There are errors in $\mathrm{V}$ when compared with $\mathrm{U}$ and $\mathrm{D}$ :

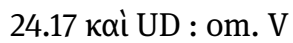

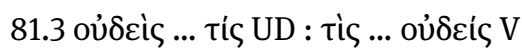

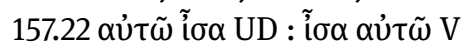

180.11 тò A UD : om. V

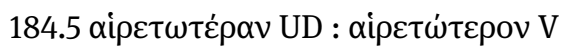

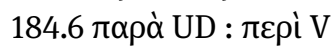

And there are also errors in D when compared with $\mathrm{U}$ and V:

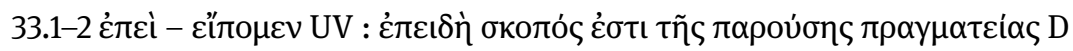

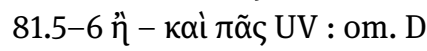

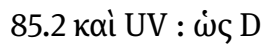

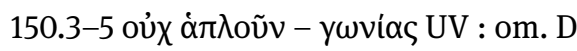

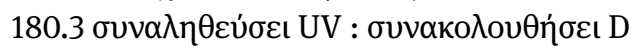

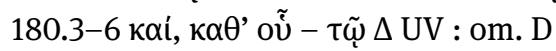

\section{Manuscripts QGILZ}

All five manuscripts transmit schol. 1 as part of Philoponos 2 (see p. XLIX). Furthermore, conjunctive errors against the witnesses transmitting schol. 1 (VFES $\beta$ Dt) make it clear that QGILZ belong to the same family.

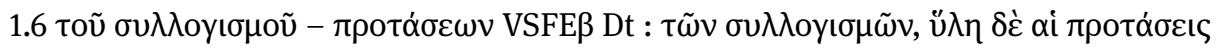
QGILZ

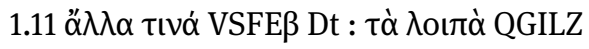

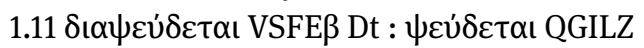

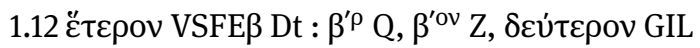

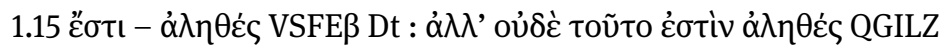

$\mathrm{Q}$ was in the possession of Manouel Evgenikos. ${ }^{72} \mathrm{G}$ and $\mathrm{Z}$ probably depend on Q. Similarities between $\mathrm{Q}$ and $\mathrm{G}$ include not only content and common readings, but also pagination, text layout, diagrams, initials, rubric and decorative elements. However, of the two G must have been copied later, since the watermark of ff. 141-145 (Magentenos' scholion on $\mathrm{f}$. 145v) date from the end of the fourteenth or the beginning of the fifteenth century. ${ }^{73}$ Furthermore, the arrangement of text diagrams in $\mathrm{G}$ indicates that features existing in $\mathrm{Q}$ were incorporated in its drafting. Another peculiarity of $\mathrm{G}$ is that the copyist supplemented the exegetic material on unequal folia inserted later. This is also the case with schol. 1 . On the other hand, $Z$ was copied by a contemporary and possible relative of Manouel Evgenikos, Ioannes Evgenikos. ${ }^{74}$ Ioannes must have had

72 RGK II, n. 344e.

73 Briquet 1977, n. 11718 (1390/1412).

74 RGK II, n. 217. 
access to Q, but his task remained incomplete, since the comments of Philoponos 2 on Anal. Pr. II were never copied onto the spacious margins of Z (ff. 244v-292v).

Furthermore, QZ transmit a shorter version of a variant in GIL (see also above, the common abbreviation in 1.12):

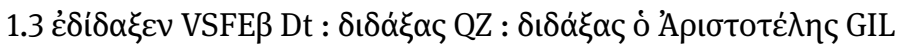

There is also a reading in Q which is slightly different in GIL. However, the respective reading in $\mathrm{Z}$ seems to be an error (homoeoarchon) due to the variant in $\mathrm{Q}$.

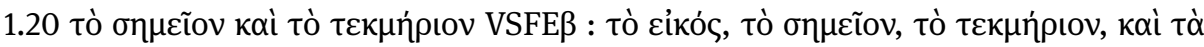

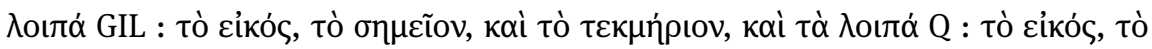

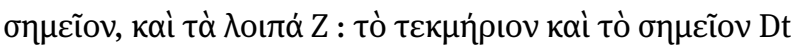

There is a separative error in $\mathrm{G}$, which was corrected in IL:

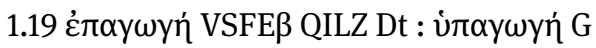

On the topic of manuscript I, it appears that Theodoros Agallianos ${ }^{75}$ (ca. 1400-1474), a collaborator of Manouel Evgenikos, probably copied passages from Anal. Pr. after $1442 .{ }^{76}$ These he then supplemented with excerpts from Philoponos 2. Manuscript I probably depends on $\mathrm{G}$, since it cannot depend on $\mathrm{Z}$ or L: there are no conjunctive errors with Z, whereas L (which does not transmit the Anal. Pr.) includes I's errors and its own separative errors.

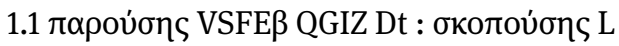

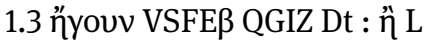

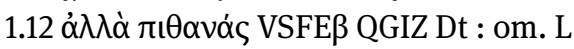

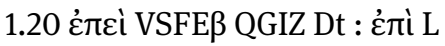

There exists one common reading of QGILZ and $\beta$. However, due to its trivial character, it is perfectly possible that this variant occurred independently in $\mathrm{Q}$ and its descendants:

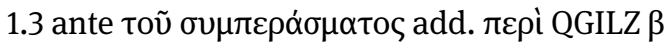

Q may depend on any one of VSF, since no error in Dt or E can be found in Q. However, there is a common omission present in $\mathrm{Q}$ and $\mathrm{F}$, namely the lemma for the Aristotelian text.

\section{Manuscripts $U^{\mathrm{a}} \mathrm{E}^{\mathrm{m}} \mathbf{M}^{\mathrm{k}} \mathbf{N}^{\mathrm{k}}$}

All four codices transmit scholion 157 as part of an anonymous commentary on Anal. Post. I 1, 71a1-b25 and, as Stefano Valente was able to convincingly show, manuscripts

75 RGK I, n. 126; II, n. 163; III, n. 208.

76 Description of the CAGB Database. 
$\mathrm{E}^{\mathrm{m}} \mathrm{M}^{\mathrm{k}} \mathrm{N}^{\mathrm{k}}$ depend on $\mathrm{U}^{\mathrm{a}} \cdot{ }^{77}$ Ioannes Argyropoulos ${ }^{78}$ (ca. 1415-1487) was the scribe of $\mathrm{U}^{\mathrm{a}},{ }^{79}$ whereas the apographa of the latter manuscript were copied by Petros Karnabakas / Karneades ${ }^{80}$ (he is the 'common denominator' in all three cases), as well as other scribes. ${ }^{81}$

The incomplete commentary on Anal. Post. I was edited by M. Hayduck ${ }^{82}$ and is the product of interpolation between the anonymously transmitted commentary on Anal. Post. in V and the scholia on its margins. ${ }^{83}$ Ebbesen's view is that this anonymous commentary should be attributed to Magentenos (see p. XXVIII). As an additional point in favour of that argument, we may add a reference to scholion 157 of Magentenos' commentary on Anal. Pr. II in the anonymous commentary on Anal. Post. I in V (f. 303r

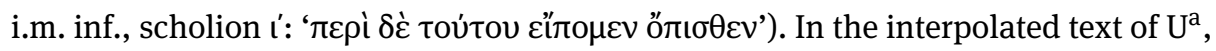
as well as in its apographa, this reference has been replaced by scholion 157 which, in turn, is an adaptation of a passage from Philoponos' commentary on Anal. Post. I. ${ }^{84}$ The outcome of such text elaboration, that is to say the presence of scholion 157 in the anonymous commentary on Anal. Post., is probably an indication, according to Valente, which hints towards the existence of a lost manuscript $v$ between $\mathrm{V}$ and $\mathrm{U}^{\mathrm{a}}$. The interpolation must have taken place in the intermediary $v .^{85}$ To be sure, this hypothesis may be correct, however nothing prevents the assumption that Ioannes Argyropoulos, the scribe of $\mathrm{U}^{\mathrm{a}}$ and a well-known Aristotelian scholar of the Renaissance, was himself perfectly capable of inserting scholion 157 in $\mathrm{U}^{\mathrm{a}}$.

$\mathrm{U}^{\mathrm{a}} \mathrm{E}^{\mathrm{m}} \mathrm{M}^{\mathrm{k}} \mathrm{N}^{\mathrm{k}}$ do not transmit any of the separative errors of PYM, whereas XR, and of course QGILZ, omit scholion 157. As can be seen, on two occasions $U^{a} E^{m} M^{k} N^{k}$ actually transmit the correct variant:

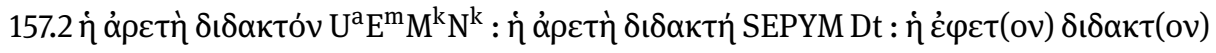

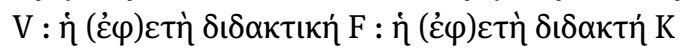

$157.5 \delta \dot{\varepsilon}^{1} \mathrm{U}^{\mathrm{a}} \mathrm{E}^{\mathrm{m}} \mathrm{M}^{\mathrm{k}} \mathrm{N}^{\mathrm{k}}$ : om. VS $\alpha \mathrm{Dt}$

77 See Valente 2021c. I am grateful to Dr. Stefano Valente for sending me the preprint version of his essay. The four manuscripts in the latter paper bear the sigla EMN and $U$ respectively. For reasons of reference and in order to avoid confusion with the sigla UEMN, which are used in this volume to declare manuscripts transmitting Anal. Pr. II or the respective commentary by Magentenos (see the sigla in sections 3.1 and 4.4), I have opted for the addition of superscripted letters (after the surnames of the scribes involved) to the sigla employed by Valente.

78 RGK, I, n. 158; II, n. 212; III, n. 263.

79 Vendruscolo 2006-07, 292, 293; Bieker 2015.

80 RGK, I, n. 346-347; II, n. 474-475; III, n. 551.

81 The text of scholion 157 in $\mathrm{E}^{\mathrm{m}}$ was copied by Nikolaos Malaxos; see Valente 2021c. On Malaxos see RGK, I, n. 312; II, n. 432; III, n. 502.

82 Hayduck 1907, vii-xviii; the manuscript in Hayduck's edition bears the siglum E. For the text of the scholion see Hayduck 1907, xiii.19-xiv.12.

83 V, ff. 301r-305r. See Ebbesen 1996, 88 (49); Ebbesen 2015, 14; Valente 2021c.

84 See apparatus fontium.

85 Valente 2021c. 


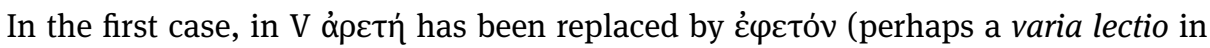
the exemplar used by the scribe of the Vaticanus). The correction might have occurred

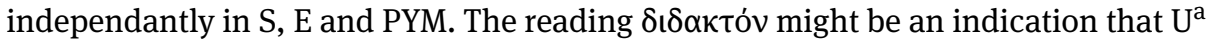
depends on $\mathrm{V}$ rather, than on one of its three descendants, namely FEK.

$\mathrm{U}^{\mathrm{a}} \mathrm{E}^{\mathrm{m}} \mathrm{M}^{\mathrm{k}} \mathrm{N}^{\mathrm{k}}$ present the following separative errors with regard to the rest of the tradition:

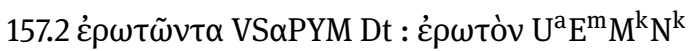

157.8 post $\varepsilon \sigma \tau \iota^{2}$ add. $\varphi \eta \sigma i(v) U^{\mathrm{a}} \mathrm{E}^{\mathrm{m}} \mathrm{M}^{\mathrm{k}} \mathrm{N}^{\mathrm{k}}:-\mathrm{VS} \alpha \mathrm{PYM} \mathrm{Dt}$

157.20 post $\Theta Z$ add. $\kappa \alpha i$ U $\mathrm{U}^{\mathrm{a}} \mathrm{E}^{\mathrm{m}} \mathrm{M}^{\mathrm{k}} \mathrm{N}^{\mathrm{k}}:-\mathrm{VS} \alpha \mathrm{PYM} \mathrm{Dt}$

There are separative errors for each of the manuscripts $E^{m} M^{k} N^{k}$ due to the script and the abbreviations in $\mathrm{U}^{\mathrm{a}}$ :

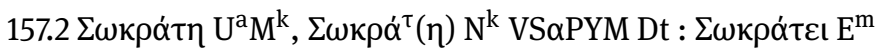

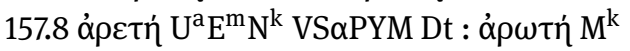

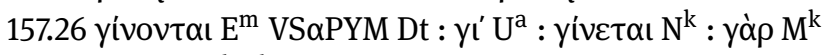

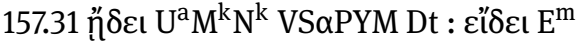

Furthermore, each of the manuscripts $\mathrm{M}^{\mathrm{k}}$ and $\mathrm{N}^{\mathrm{k}}$ has its own separative errors when compared to the rest of the family members:

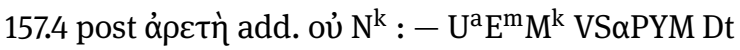

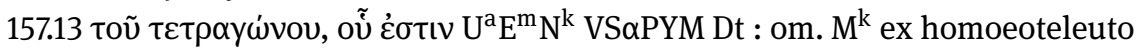

157.16-17 АВГ $\Delta \mathrm{U}^{\mathrm{a}} \mathrm{E}^{\mathrm{m}} \mathrm{N}^{\mathrm{k}}$ VS $\alpha \mathrm{PYM} \mathrm{Dt}$ : АВГ $\mathrm{M}^{\mathrm{k}}$

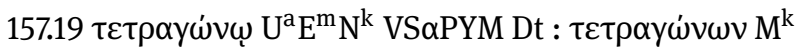

In the stemma codicum on the following page, sigla of texts with attached diagrams are printed in bold, interpolations are printed with dashed lines, and dubious relations are printed with dotted lines. (On the textual tradition of the commentary by Magentenos on Anal. Pr. see also pp. XXIX, XLVII.) 


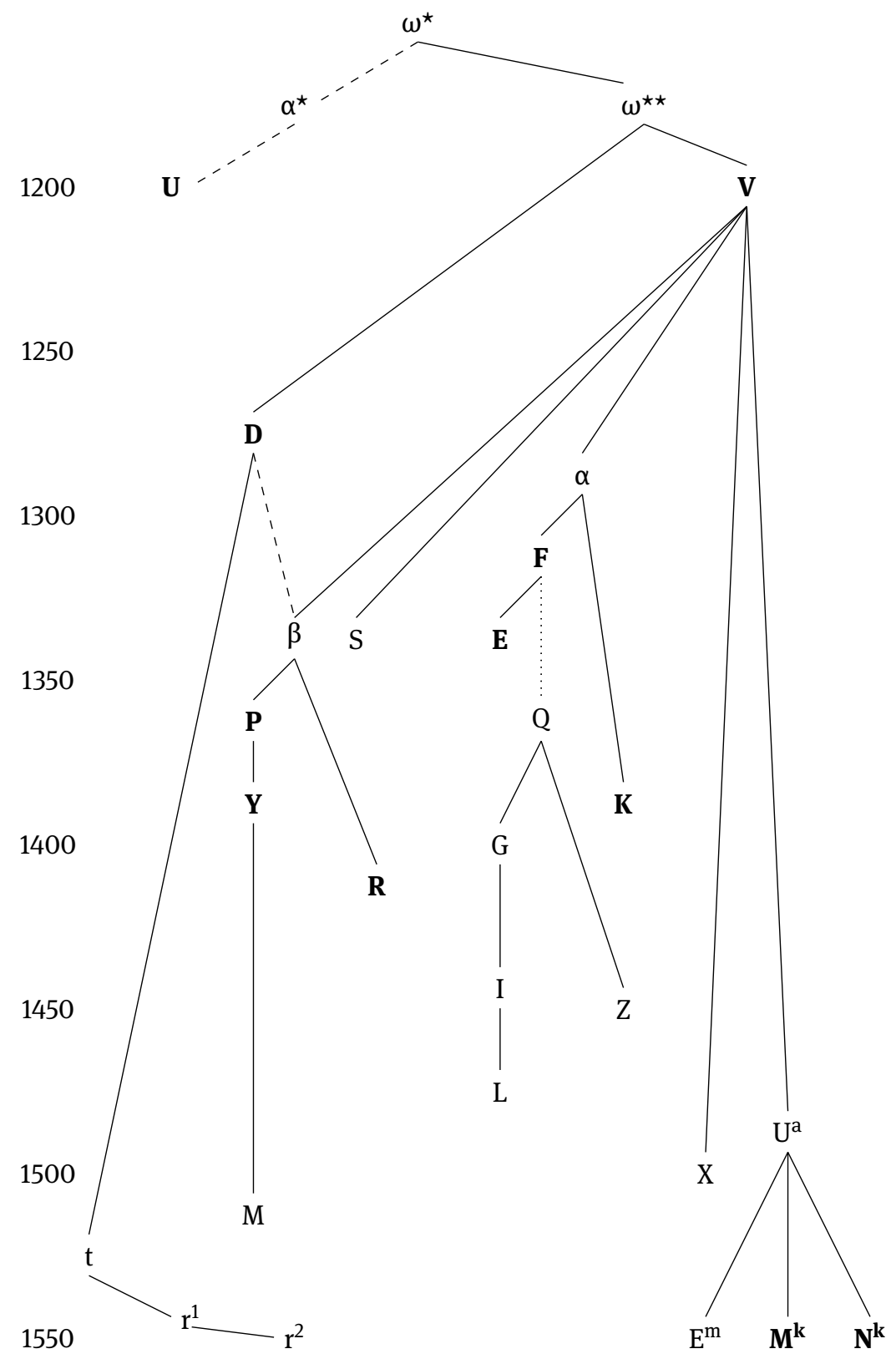

